University of Chicago Law School

Chicago Unbound

Journal Articles

Faculty Scholarship

1989

\title{
The Grand Illusion: A Neutral System for the Taxation of International Transactions
}

Julie Roin

Follow this and additional works at: https://chicagounbound.uchicago.edu/journal_articles

Part of the Law Commons

\section{Recommended Citation}

Julie Roin, "The Grand Illusion: A Neutral System for the Taxation of International Transactions," 75

Virginia Law Review 919 (1989).

This Article is brought to you for free and open access by the Faculty Scholarship at Chicago Unbound. It has been accepted for inclusion in Journal Articles by an authorized administrator of Chicago Unbound. For more information, please contact unbound@law.uchicago.edu. 


\title{
VIRGINIA LAW REVIEW
}

\begin{tabular}{lll}
\hline \hline VOLUME 75 & AUGUST 1989 & NUMBER 5 \\
\hline
\end{tabular}

ARTICLES

\section{THE GRAND ILLUSION: A NEUTRAL SYSTEM FOR THE TAXATION OF INTERNATIONAL TRANSACTIONS}

\author{
Julie A. Roin*
}

T IKE most parts of the Internal Revenue Code (the Code), ${ }^{1}$ SubLchapter $\mathbf{N},{ }^{2}$ the portion detailing the taxation of income from international transactions, has been the subject of almost constant congressional tinkering in recent years. ${ }^{3}$ Each of the many tax acts promulgated during the past decade has amended-often substan-

* Assistant Professor of Law, University of Virginia School of Law. Thanks are due to my colleagues Saul Levmore, Stanford Ross, and Paul Stephan for their helpful comments on an earlier draft of this Article.

1 All references to "the Code" herein, except as specifically noted, will be to the Internal Revenue Code of 1986, as amended, or to its immediate predecessor, the Internal Revenue Code of 1954, as amended, codified at 26 U.S.C. [I.R.C.] $\$ \S 1-9602$ (1982 \& Supp. V 1987). References to particular sections of the Code will be to the version of the Code in effect on January 1, 1989, unless otherwise noted.

2 Subchapter $\mathbf{N}$ of Chapter 1, entitled "Tax Based on Income from Sources Within or Without the United States," encompasses $\$ 861$ through 999 of the Code.

3 See Apolinsky, The Changes Just Cost Money, Wash. Post, Apr. 6, 1986, at C8, col. 1 (5815 Code sections amended since 1976, 3302 amended since 1981). The accelerating rate and decreasing durability of tax reform programs have elicited much comment in recent years. For a detailed study of changes in the rate of tax reform, see J. Witte, The Politics and Development of the Federal Income Tax 67-244 (1985). One pair of scholars attributes the recent increase in the rate of tax reform to changes in the legislative process that encourage legislators and potentially affected taxpayers to enter into short-term rather than long-term "contracts" regarding the content of tax rules. Doernberg \& McChesney, On the Accelerating Rate and Decreasing Durability of Tax Reform, 71 Minn. L. Rev. 913, 959-60 (1987). 
tially-its provisions. ${ }^{4}$ As has been the case with most of the "reforms" enacted during this period, these changes complicated, rather than simplified, the preexisting rules. ${ }^{5}$ These rules were among the most arcane and complex in the Code at the inception of this process; ${ }^{6}$ they are now unparalleled in their intricacy. ${ }^{7}$

Many of the recent reforms in the international tax rules have been aimed at satisfying a perennial complaint lodged by critics of the income tax system: that the rules for the taxation of income earned abroad by American business enterprises encourage the expatriation of this country's economic base, adding to, if not causing, its econoinic woes. ${ }^{8}$ In the Tax Reform Act of $1986,{ }^{9}$ for exainple, Congress

4 See, e.g., Tax Reform Act of 1986, Pub. L. No. 99-514, $\S \S 1201-1277,100$ Stat. 2085, 2520-602; Deficit Reduction Act of 1984, Pub. L. No. 98-369, $\S \S 121-139,801-805$, 98 Stat. 494, 638-77, 985-1003; Tax Equity and Fiscal Responsibility Act of 1982, Pub. L. No. 97-248, $\S \S 211-213$, 96 Stat. 324, 448-66; Economic Recovery Tax Act of 1981, Pub. L. No. 97-34, $\S \S 831-832$, 95 Stat. 172, 352-55; Foreign Earned Income Act of 1978, Pub. L. No. 95-615, $\S \S$ 201-209, 92 Stat. 3098, 3098-109; Tax Reform Act of 1976, Pub. L. No. 94-455, $\S 1011-$ 1101,90 Stat. $1520,1610-60$.

5 See R. Kaplan, Federal Taxation of International Transactions 3-4 (1988).

6 See R. Gordon, Tax Havens and Their Use by United States Taxpayers-An Overview: A Report to the Commissioner of Internal Revenue, the Assistant Attorney General (Tax Division), and the Assistant Secretary of the Treasury (Tax Policy) 7 (1981); Tillinghast, United States Income Taxation of Foreign Source Income: A Survey of the Provisions and Problems, 29 N.Y.U. Inst. on Fed. Tax'n 1, 2 (1971).

7 See R. Kaplan, supra note 5, at 4; Ross, International Tax Law: The Need for Constructive Change, in Tax Policy in the Twenty-First Century 87, 94 (H. Stein ed. 1988).

8 Prior to 1954, Congress self-consciously utilized the tax system to promote foreign trade and investment. See Jenks, Taxation of Foreign Income, 42 Geo. Wash. L. Rev. 537, 537 (1974); U.S. Comm'n on Foreign Economic Policy, Report to the President and the Congress 14-23 (1954). The only questions raised in that era seemed to be whether additional tax incentives should be provided, and if so, the precise form these incentives should take. See, e.g., E. Barlow \& I. Wender, Foreign Investment and Taxation at xvii-xxv (1955); Carroll, Developments in International Tax Law in 1937, 16 Tax Mag. 75 (1938); Magill \& Schaab, American Taxation of Income Earned Abroad, 13 Tax L. Rev. 115 (1958); Surrey, Current Issues in the Taxation of Corporate Foreign Investment, 56 Colum. L. Rev. 815, 858-59 (1956).

By the late 1950's, however, persistent balance of payment and trade problems caused a number of politicians and academics to rethink the desirability of the "existing artificial stimul[i] to ... capital movements." L. Krause \& K. Dam, Federal Tax Treatment of Foreign Income 6 (Brookings Institution Studies of Government Finance 1964). In 1961, convinced that "there are no longer foreign policy reasons for providing tax incentives for foreign investment in the economically advanced countries," President Kennedy proposed sweeping changes in the international tax rules that would substantially eliminate those "features of our tax system which, in conjunction with the tax system of other countries, consistently favor U.S. private investment abroad compared with investment in our own.economy" in order to be "consistent with the efficient distribution of capital resources in the world, our balance of 
reworked the foreign tax credit limitation scheme, ${ }^{10}$ elaborated several income and expense allocation rules, ${ }^{11}$ redesigned some source rules, ${ }^{12}$ and devised a new subregime for certain types of investment income ${ }^{13}$-all to overcome the "tilt [in] the relative balance of U.S. tax rules favoring foreign investment and U.S. tax rules favoring U.S.

payments needs, and fairness to competing firms located in our own country." President's Special Message to the Congress on Taxation, 1961 Pub. Papers 290, 294-96, H.R. Doc. No. 140,87 th Cong., 1st Sess. 6-7, reprinted in 1961 U.S. Code Cong. \& Admin. News 1129, $1133-$ 34. Congress's decision to adopt only a truncated version of the President's original proposal, see S. Rep. No. 1881, 87th Cong., 2d Sess. 78, reprinted in 1962 U.S. Code Cong. \& Admin. News 3297, 3381, satisfied neither those who believed the original tax incentives should have been restored or even expanded, see, e.g., Choate, Hurok \& Klein, Federal Tax Policy for Foreign Income and Foreign Taxpayers-History, Analysis and Prospects, 44 Temp. L.Q. 441 (1971); Slowinski, Commentary on the Administration's 1961 Recommendations on Tax Treatment of Foreign Income, 13 Tax Executive 268 (1961); Smith, Tax Policy and Foreign Investment, 34 Law \& Contemp. Probs. 146 (1969), nor those who believed that, at the very least, all incentives for foreign investment should be removed from the tax system, see, e.g., Federal Tax Reform for 1976, at 77-92 (S. Surrey, P. McDaniel \& J. Pechman eds. 1976); P. Musgrave, United States Taxation of Foreign Investment Income: Issues and Arguments 107 (1969); Gumpel, The Taxation of American Business Abroad-Is Further Reform Needed?, 15 J. Int'l L. \& Econ. 389 (1981); Schmidt, U.S. Capital Export Policy: Backdoor Mercantilism, in U.S. Taxation of American Business Abroad 7, 16-19 (American Enterprise Institute-Hoover Policy Study No. 16, 1975); Stone, United States Tax Policy Toward Foreign Earnings of Multinational Corporations, 42 Geo. Wash. L. Rev. 557 (1974).

Though the general outlines of the 1962 compromise survived numerous legislative initiatives in both directions, see Pugh, The Deferral Principle and U.S. Investment in Developing Countries, in United States Taxation and Developing Countries 267, 272-78 (R. Hellawell ed. 1980) (outlining legislative initiatives in international tax arena), over time Congress has made numerous minor amendments to the rules to further the cause of "neutrality." See, e.g., Senate Comm. on Finance, 98th Cong., 2d Sess., Deficit Reduction Act of 1984, Explanation of Provisions Approved by the Committee on March 21, 1984, at 349 (Comm. Print 1984) (reason for changing tax treatment of income from factoring trade receivables to prevent "foreign investment [from being] preferable to U.S. investment, contrary to the basic principle of capital export neutrality"); id. at 392 (recharacterizing dividend income as interest income for foreign tax credit purposes because "[c]urrent law, by encouraging U.S. taxpayers to invest capital outside the United States, erodes the U.S. tax base"); Staff of Joint Comm. on Tax'n, 94th Cong., 2d Sess., General Explanation of the Tax Reform Act of 1976, at 228 (1976) (statute taxing investment of foreign profits of U.S. owned corporation in U.S. property amended because it "encourag[ed] foreign corporations to invest their profits abroad"); id. at 230 (incentive to invest in less developed countries repealed because "the Congress believes that it would be preferable to provide whatever assistance is appropriate ... in a direct manner where the economic costs can be accurately measured").

9 Pub. L. No. 99-514, 1986 U.S. Code Cong. \& Admin. News (100 Stat.) 2085 (codified in scattered sections of 26 U.S.C. (1982 \& Supp. V 1987)).

10 Id. $\S \S 1201-1205,1986$ U.S. Code Cong. \& Admin. News (100 Stat.) at 2520-33.

11 Id. $\S \S 1215-1216,1986$ U.S. Code Cong. \& Admin. News (100 Stat.) at 2544-49.

12 Id. $\S \S 1211-1214,1986$ U.S. Code Cong. \& Admin. News (100 Stat.) at 2533-44.

13 Id. $\S 1235,1986$ U.S. Code Cong. \& Admin. News (100 Stat.) at 2566-76. 
investment in favor of foreign investment."14

Unfortunately, however, despite their complexity, these latest reform efforts are no more likely to correct the tax system's bias in favor of foreign investment-that is, the exportation of U.S. capital abroad-than previous reform efforts have been. It is even possible that they will worsen the situation rather than improve it. The reason for this gloomy prognostication is that these reforms, like the ones that preceded them, are directed toward symptoms of the problem rather than its underlying cause-the structure of the tax credit mechanism. Until Congress understands the true causes of the "tilt" in the tax rules, attempts to ameliorate it will be unsuccessful.

This is not to suggest that elimination of the bias can be done quickly, cheaply, or without controversy. As explained in Part I of this Article, the bias is not only deeply entrenched in our tax system, but also protected and exacerbated by other countries that it benefits. The reforms required to overcome the bias, detailed in Part II, may create as many problems as they solve. Thus, in Part III, I reach the ultimate question: whether neutrality ${ }^{15}$ should be a goal of our international tax rules, or whether it should be sacrificed to other, more pressing goals-especially in light of our new status as an overall capital-importing, rather than capital-exporting, nation. ${ }^{16}$ It is a question that has been studiously avoided by politicians and policyinakers, quick to assume that they can have everything if they just tinker with the tax system a little more. As this Article explains, however, hard choices will have to be made.

14 Staff of Joint Comm. on Tax'n, 99th Cong., 1st Sess., General Explanation of the Tax Reform Act of 1986, at 862 (Joint Comm. Print 1987) [hereinafter 1986 General Explanation].

is That is, neutrality with respect to investment decisions, the type of neutrality referred to as "capital export neutrality." Under a capital export neutral tax system, tax considerations play no part in a taxpayer's decision whether to invest capital at home or abroad. See Hufbauer \& Foster, U.S. Taxation of the Undistributed Income of Controlled Foreign Corporations, in Essays in International Taxation: 1976, at 1, 14-15 (Dep't of the Treasury, Tax Policy Research Study No. 3, 1977). In fact, the goal sought by Congress and labeled in this Article as "defensive neutrality" is not pure capital export neutrality, but a circumscribed variant thereof. See infra notes $46-47$ and accompanying text.

16 See Woodard, The IRS Redirects Its International Program, 41 Tax Notes 455, 455-56 (1988) (using U.S. Department of Commerce figures to show that by 1986, there were more foreign-owned assets in the United States than there were U.S. assets abroad). 


\section{The Taxation of Foreign-Source InCOME}

The United States, like most countries, claims jurisdiction to tax its resident individuals and domestic corporations ${ }^{17}$ on their total, worldwide income, wherever derived. ${ }^{18}$ In fact, the United States goes slightly beyond the norm, asserting authority to tax its nonresident citizens' incomes, wherever derived. ${ }^{19}$ Since most countries, including the United States, also claim the right to tax all income derived within their borders, U.S. citizens, residents, and corporations earning income abroad may be subject to two or more sets of national taxes on the same income. ${ }^{20}$ If each country collects its full tax levy without regard to taxes collected by other national jurisdictions, the total tax burden could conceivably exceed the taxpayer's income. Since the obvious end result of such multiple levies would be the virtual cessation of international trade and business, ${ }^{21}$ most countries agree that some accommodation needs to be made for the international taxpayer. The consensus that has evolved requires the "residence country" 22 to make the accommodation-and suffer the consequent loss of tax revenue. ${ }^{23}$ Over time, residence countries have developed several different methods of eliminating "double taxation." 24 The two most com-

17 A domestic corporation is a corporation "created or organized in the United States or under the law of the United States or of any State." I.R.C. \$ 7701(a)(4) (1982).

18 See I.R.C. $\S 61$ (a) (Supp. V 1987) ("[G]ross income means all income from whatever source derived."). No provision elsewhere in the Code allows resident individuals or domestic corporations to exclude or deduct foreign-source income when calculating taxable income. See 3 B. Bittker, Federal Taxation of Income, Estates and Gifts \ 65.1 (1981).

19 R. Hellawell \& R. Pugh, Taxation of Transnational Transactions 1987-1988, at 47 (1987); see also Cook v. Tait, 265 U.S. 47 (1924) (upholding Congress's power to tax foreignsource income derived by nonresident citizens).

${ }^{20}$ See Federal Income Tax Project, International Aspects of United States Income Taxation 307 (A.L.I. 1987); R. Hellawell \& R. Pugh, supra note 19, at 101; R. Kaplan, supra note 5, at 8.

21 See Federal Income Tax Project, supra note 20, at 307; R. Hellawell \& R. Pugh, supra note 19 , at 101 .

22 That is, the country where the taxpayer resides (or of which the taxpayer is a citizen).

23 J.D.R. Adams \& J. Whalley, The International Taxation of Multinational Enterprises in Developed Countries 53 (1977); Federal Income Tax Project, supra note 20, at 6.

24 The term "double taxation," which has pejorative connotations, is used in this Article to refer to situations in which a taxpayer is required to pay two analogous sets of national income taxes on the same income. This should not be confused with the phenomenon of "two-tier taxation," which refers to the common practice of subjecting corporate income to two different income tax levies, one at the corporate level on all income earned by the corporation, and the second at the shareholder level, by including dividend income in the shareholder's taxable income. This practice is discussed infra notes $93-100$ and accompanying text. 
monly used methods are tax exemption and tax credit; each has its advantages and disadvantages.

Residence countries that utilize an exemption system ${ }^{25}$ "exempt" most foreign-source income from their own income tax base. ${ }^{26}$ Hence, a taxpayer pays only one national income tax on each portion of his income, the tax levied by the country in which the income is derived. ${ }^{27}$ If the tax levy of this "source country" is higher than that of the residence country, the taxpayer's after-tax profit is less than that of investors earning similar pre-tax returns in the taxpayer's home country. If this is the case, capital export is relatively less attractive than capital retention. ${ }^{28}$ Conversely, if the source country's

25 This form of double taxation relief may be guaranteed by a country's domestic law, see J.D.R. Adams \& J. Whalley, supra note 23, at 59 (Brazil, France, and Holland use exemption systems); Vogel, The Search for Compatible Tax Systems, in Tax Policy in the Twenty-First Century 76, 79 (H. Stein ed. 1988) (Switzerland, the Netherlands, Anstralia, Argentina, Uruguay, Hong Kong, France, and Brazil all use variants of an exemption system), or may be made available only pursuant to a treaty obligation, see, e.g., Convention for the Avoidance of Double Taxation With Respect to Taxes on Income, July 22, 1954, United States-West Germany, art. 15(1)(b)(aa), 5 U.S.T. 2768, 2798, T.I.A.S. No. 3133, as amended by Protocol, Sept. 17, 1965, 16 U.S.T. 1875, 1886, T.I.A.S. No. 5920 (Germany excludes from taxation dividends received from U.S. corporation in which German company owns at least $25 \%$ of the voting stock).

26 See J.D.R. Adams \& J. Whalley, supra note 23, at 53. In fact, few countries provide a blanket exemption for foreign-source income, although the particular restrictions imposed vary from jurisdiction to jurisdiction. France, for example, exempts only foreign-source business income from French corporation tax; other income (such as passive income) is taxed on a worldwide basis. Arnold, Introduction, in Taxation of Domestic Shareholders on Undistributed Income of Foreign Corporate Affiliates: Objectives, Techniques and Consequences 1, 1 (1987) (Seminar held during the 40th (1986) congress of the International Fiscal Association); id. at $42-43$ (comments of Dominique Lemaire, Le Sous Directeur, Service de la législation fiscale, Relations internationales, Ministère de l'économie, des finances et de la privatisation). The Netherlands imposes special limits on the exemption privilege when it has no tax treaty with the country in which the income is derived. Id. at 96 (comments of Dick Hund, Senior Vice President Taxes, Royal Douwe Egberts N.V., Utrecht, formerly Deputy Director for International Fiscal Affairs). The integration of corporate and personal income taxes also tends to limit the extent of tax relief provided by exemption systems. See infra note 137.

27 J.D.R. Adams \& J. Whalley, supra note 23, at 54 (Table 1).

28 See R. Caves, Multinational Enterprise and Economic Analysis 227-28 (1982) (providing numerical example). This assumes, of course, that the difference in tax rates does not reflect merely a difference in the level of governmental services provided to the taxpayer and, further, that the low-tax jurisdiction does not compensate for the low rate of income tax by exacting heavier taxes of another kind. Intelligent entrepreneurs do not decide where to locate their businesses based on tax costs alone, and especially not on the basis of the cost of a single tax in a multi-tax jurisdiction (unless that one tax exceeds the total tax levy in a competing jurisdiction). In many cases, an apparent disparity in tax rates between jurisdictions may be 
tax levy is lighter than that of the residence country, the taxpayer profits from the differential-after-tax returns in foreign investments exceed the returns available through domestic investments offering similar pre-tax returns. Hence, the exemption system provides an economic incentive for residents to invest in low-tax countries ${ }^{29}$ and not to invest in those with high tax rates. ${ }^{30}$

The mechanism used by the United States to ameliorate the problem of double taxation is the foreign tax credit. ${ }^{31}$ Unlike the exemption system, the foreign tax credit is supposed to eliminate the incentive to invest in low-tax countries. ${ }^{32}$ Adopted by Congress in $1918,^{33}$ the credit mechanism remains today as the centerpiece of the

partially or completely explained by such factors. See P. Musgrave, supra note 8 , at 116-17; Vogel, supra note 25 , at 81-82. However, it strains credulity to believe that, after these factors are taken into account, all jurisdictions levy identical tax burdens. See P. Musgrave, supra note 8, at 117 ("[T]ax rates are likely to differ more than benefit rates."); cf. Bird, Shaping a New International Tax Order, 42 Bull. for Int'l Fiscal Documentation 292, 296 (1988) ("[I]t is wrong to assume that all developing countries are low-tax countries or that, especially where foreign investment is concerned, all low-tax countries are developing countries.") (citations omitted).

${ }^{29}$ U.N. Centre on Transnat'l Corps., International Income Taxation and Developing Countries 18, U.N. Doc. ST/CTC/56, U.N. Sales No. E.88.II.A.6 (1988); Gumpel, supra note 8 , at $400-01$.

30 See Kingson, The Coherence of International Taxation, 81 Colum. L. Rev. 1151, 1235-36 (1981) (noting that if the United States utilized an exemption system, U.S. investment in Canada and Brazil would be deterred by those countries' high tax rates).

31 Statutory authority for the tax credit can now be found at I.R.C. $\$ \S 901-906$ (1982 \& Supp. V 1987).

32 Although there is no direct evidence that Congress thought about the credit in these terms, see infra note 33 , later commentators point to this quality as the credit's chief advantage. See, e.g., P. McDaniel \& H. Ault, Introduction to United States International Taxation 127 (1981); U.N. Centre on Transnat'l Corps., supra note 29, at 20; Forry \& Lerner, Taxing Multinational Enterprises: Basic Issues of International Tax Harmonization, 10 Int'l Law. 623, 628 (1976); see also sources cited infra note 39 (explaining how the tax credit transfers the benefits of investments in low-tax jurisdictions from the taxpayer to the United States Treasury).

33 Revenue Act of 1918, $\S \S 222$ (individuals), 238 (corporations), Pub. L. No. 65-254, 40 Stat. 1057, 1073-74, 1080-81. From the inception of the income tax in 1916 until 1918, taxpayers were allowed to deduct foreign taxes (as well as all state taxes) when computing their net income for tax purposes. See Revenue Act of 1916, $\$ \S 5$ (a)(3) (individuals), 12(a)(4) (corporations), Pub. L. No. 64-271, 39 Stat. 756, 759, 768; H.R. Rep. No. 767, 65th Cong., 2d Sess. (1918) reprinted in 63 Internal Revenue Acts of the United States 1909-1950: Legislative Histories, Laws, and Administrative Documents 12-13 (B. Reams ed. 1979). As tax rates rose in response to the fiscal demands imposed by World War I, however, Congress felt compelled to reduce the burden of double taxation. Id. Though Thomas Adams (a professor of political economy at Yale who served as a tax adviser to the Treasury Department during the war years), the self-proclaimed author of the tax credit scheme, attributes its adoption "[i]n the 
Code's scheme for the taxation of foreign-source income. ${ }^{34}$ The basic mechanism is quite simple: Taxpayers generate one dollar of tax credit for each dollar of foreign income tax they pay or accrue during the course of a year. ${ }^{35}$ This credit can then be used to offset the taxpayer's federal income tax liability for the same year. ${ }^{36}$ If the source country's tax equals or exceeds the taxpayer's federal income tax liability, the taxpayer is excused from any further federal tax liability. ${ }^{37}$ Unlike an exemption system, however, if the source country levy is lower than the federal tax liability, the taxpayer must pay the differential to the United States Treasury. ${ }^{38}$ The benefits of engaging in business in a low-tax jurisdiction thus redound to the United States, not to the taxpayer, and the taxpayer has no economic incentive to search out low-tax jurisdictions. ${ }^{39}$

The following example illustrates the beauty of the credit mechanism. Suppose an American citizen, trying to decide where to invest $\$ 1,000,000$, narrows his choices to two alternatives: a bank in Hong Kong, paying 5\% interest, or a bank in the United States, paying $6 \%$

midst of the war, when the financial burden upon the United States was greater than it had ever been" to its "touch[ing] the equitable chord or sense," Adams, International and Interstate Aspects of Double Taxation, 22 Proc. of the Nat'1 Tax Ass'n 193, 198 (1930), the very limited legislative record suggests its adoption stemmed at least as much from fears that taxpayers would solve the matter themselves through expatriation or the formation of foreign corporations, thus costing the United States Treasury even more money. See Hearings on the Revenue Act of 1918 Before the House Comm. on Ways and Means, 65th Cong., 2d Sess. 649 (1918) (statement of Mr. Eder, Secretary, Mercantile Bank of the Americas); 56 Cong. Rec. app. 677-78 (1918) (colloquy between Reps. Borland and Kitchin), reprinted in J. Seidman, Seidman's Legislative History of Federal Income Tax Laws 1938-1861, at 928 (1938). See generally Surrey, supra note 8, at 817-19 (discussing "somewhat obscure" origin of foreign tax credit).

34 See R. Kaplan, supra note 5, at 81; Dale, The Reformed Foreign Tax Credit: A Path Through the Maze, 33 Tax L. Rev. 175, 175 (1978).

35 I.R.C. $\$ 901$ (b) (1982).

36 I.R.C. $\$ 901$ (a) (Supp. V 1987). Under certain circumstances, a domestic corporation that owns shares of a foreign subsidiary may claim credit for income taxes paid by its subsidiary in addition to claiming credit for foreign income taxes paid or accrued by the parent itself. See I.R.C. $§ 902$ (Supp. V 1987).

37 Federal Income Tax Project, supra note 20, at 307; M. Moore, U.S. Tax Aspects of Doing Business Abroad 101-02 (American Institute of Certified Public Accountants, Studies in Federal Tax'n No. 6, 1983). Foreign income taxes may not discharge the taxpayer's entire federal minimum tax obligation, however. See I.R.C. § 59(a)(2) (Supp. V 1987) (limiting alternative minimum tax foreign tax credit to $90 \%$ of minimum tax amount).

38 R. Hellawell \& R. Pugh, supra note 19, at 101-02; M. Moore, supra note 37, at 101.

39 See R. Kaplan, supra note 5, at 105; U.N. Centre on Transnat'l Corps., supra note 29, at 21; Hufbauer \& Foster, supra note 15, at 14-15. 
interest. Assume for purposes of this example that both accounts will be held in dollars and that the banks are equally risky. Absent tax considerations, the citizen would invest his money in the American bank because it offers a higher rate of return. But suppose Hong Kong levies income tax on interest income at a $10 \%$ rate, while the United States taxes interest at a $28 \%$ rate. Under an exemption system, the citizen would invest his money in Hong Kong, because $\$ 50,000$ taxed at $10 \%$ leaves $\$ 45,000$, while $\$ 60,000$ taxed at $28 \%$ yields only $\$ 43,200$. Under the foreign tax credit system, however, the Hong Kong investment would generate pre-credit U.S. income tax liability of $\$ 14,000$ (28\% of $\$ 50,000)$. Against this liability, the taxpayer could claim $\$ 5000$ of credit for Hong Kong taxes, leaving $\$ 9000$ of residual liability. Because the Hong Kong investment now yields only $\$ 36,000$ ( $\$ 45,000$ after Hong Kong taxes, less $\$ 9000$ of residual U.S. $\operatorname{tax}$ ), the citizen would put his money in the U.S. bank (with an after-tax return of $\$ 43,200$ ), just as he would in a world without taxes. In short, the foreign tax credit mechanism removes the competitive advantage enjoyed by low-tax countries under an exemption system and forces investors to base business decisions on nontax, economic considerations. $^{40}$

The results in more complicated, real-world situations, however, are not nearly so neat as those suggested by this stylized example. Problems arise from two causes: high-tax jurisdictions and two-tier systems for the taxation of corporate income.

\section{A. The Dilemma Posed by High-Tax Jurisdictions}

When only one foreign jurisdiction is involved, and that jurisdiction's income tax levy is less than that assessed by the United States, the foreign tax credit mechanism prevents tax considerations from intruding into the business decision of whether to locate income-producing activities in the United States or abroad. In theory, the tax credit could be used to achieve the same neutrality for choices between investments in the United States and in jurisdictions with higher tax rates. To attain such neutrality, however, the United States would have to refund any foreign tax credit that remains after

40 See U.N. Centre on Transnat'I Corps., supra note 29, at 20-21. At least, this is the case when the taxpayer has no other foreign-source income. Id.; see infra text accompanying notes 41-68. 
the taxpayer's U.S. income tax liability has been eliminated. ${ }^{41}$

To illustrate, suppose the citizen in the above example was trymg to decide whether to invest his $\$ 1,000,000$ in the U.S. bank or in a German bank that also pays $6 \%$ interest. Assume that Germany taxes interest income at a $45 \%$ rate. If the citizen places his funds in the German bank, he will have a German tax obligation of $\$ 27,000$. His after-tax income would be $\$ 33,000-\$ 10,200$ less than the after-tax return from an identical investment in the U.S. bank. His federal income tax liability of $\$ 16,800$ (28\% of $\$ 60,000$ ), however, would be completely eliminated by his foreign tax credit. In fact, the taxpayer would have $\$ 10,200$ more credit than necessary to eliminate his federal tax obligation-an excess corresponding exactly to the shortfall resulting from the higher German tax rate. If Congress allowed the taxpayer to cash in his excess tax credit, either by granting him a refund or by allowing him to use it against taxes due on other income, the taxpayer would obtain the same after-tax return from his German investment as he would from an American one. Neutrality would be achieved. ${ }^{42}$

Guaranteeing neutrality in this way, however, allows source countries to exploit the United States. ${ }^{43}$ If the United States indiscriminately absorbs the costs of excess foreign taxation through the operation of its credit program, a source country could raise its taxes on income earned by U.S. investors with impunity. Indemnified against this extra expense by the U.S. government, investors would not object to the imposition of additional foreign taxes, nor would such levies make them less likely to invest in the source country. ${ }^{44}$ In short, source countries would have everything to gain and nothing to lose by levying Draconian taxes on U.S. investors. ${ }^{45}$ Governments are

41 See P. McDaniel \& H. Ault, supra note 32, at 101; P. Musgrave, supra note 8, at 147; Hufbauer \& Foster, supra note 15, at 14; Surrey, supra note 8, at 824.

42 See supra note 15 (defining "capital export neutrality").

43 See P. McDaniel \& H. Ault, supra note 32, at 101 (unlimited credit mechanism "puts the U.S. Treasury at the disposal of all foreign tax systems"); Hufbauer \& Foster, supra note 15, at 16 ("If the excess credit could be claimed without limit, foreign governments could erode U.S. tax revenues on domestic source income.").

44 See R. Kaplan, supra note 5, at 105 (providing example of how "the foreign country profits mightily from its 'high' tax rate, [while] the taxpayer is indifferent ... and Uncle Sam loses big"); Kingson, supra note 30, at 1244 ("American investors will accept higher source taxation because the Treasury bears it.").

45 Higher tax rates may discourage other investors, thus offsetting the benefit the source country receives from increasing taxes on U.S. investors. See Sugarman, Current Issues in 
not known for turning down "free" revenues, and it is hard to believe that many would resist the temptation. Although the United States has traditionally dispensed a fair amount of foreign aid, distributing it in this fashion-largely beyond congressional oversight both as to amount and use-hardly seems desirable.

Fear of this sort of looting of the federal treasury led Congress to decide, early in its use of the tax credit mechanism, against granting refunds or offsets for foreign tax credit in excess of the federal income tax liability on foreign-source income. ${ }^{46}$ Congress thus compromised the goal of absolute neutrality by institutionalizing a more self-protective variant that this Article refers to as "defensive" neutrality-that is, neutrality to the extent possible without subsidization of countries

Taxation of Business Investment Abroad, 17 Ohio St. L.J. 277, 283-84 (1956) (enacting taxes for which United States allows credit would be "comparatively painless" for the source country, "except to the extent that the foreign country may thereby impose a tax on its own corporations"). Such countervailing losses can be avoided, however, if the source country directs its tax increases solely at U.S. investors. Although, theoretically, foreign tax credit cannot be generated by payment of discriminatory "soak-up" taxes, see Treas. Reg. $\S 1.901$ 2(c)(1) (1988) (tax will be considered an "income tax" eligible for credit "only to the extent that liability for the foreign tax is not dependent (by its terms or otherwise) on the availability of a credit for the tax against income tax liability to another country"), in practice this restriction is often violated because of political concerns or administrative difficulties in proving the discriminatory nature of the levy. See, e.g., Kingson, supra note 30, at 1186 \& nn.176-77 (describing U.S. assent to discriminatory taxation effected through source countries' denials of deductions for business expenses); Surrey, Some Foreign Tax Credit Issues in Relation to Developing Countries: Withholding Taxes on Interest Payments and Discriminatory Taxes, in United States Taxation and Developing Countries 385, 399-401 (R. Hellawell ed. 1980) (describing "a number of instances in which such discriminatory taxes have been, or are being, utilized by developing countries"). See also supra note 137 (discussing integrated tax systems).

46 See Revenue Act of 1921, Pub. L. No. 67-98, §§ 222(a)(5) (individuals), 238(a) (corporations), 42 Stat. 227, 249, 258 (1921) (limiting foreign tax credit to proportion of federal tax liability that taxpayer's foreign source income bears to his total income). Since the income tax laws at no time provided taxpayers with a right to refunds for foreign taxes paid in excess of U.S. income tax liability, Congress's fear of other countries' overreaching was limited to concern that "this credit may wipe out part of our tax properly attributable to income derived from sources within the United States." H.R. Rep. No. 350, 67th Cong., 1st Sess. 13 (1921). See also Internal Revenue: Hearings on H.R. 8245 Before the Senate Comm. of Finance, 67th Cong., 1st Sess. 74 (1921) [hereinafter 1921 Hearings] (statement of Dr. Adams, tax adviser to the Treasury Department):

While I do not want to state that anybody has sought to abuse it, we know of instances where big corporations whose income was derived largely from this country have had their tax wiped out, so far as this country is concerned, because the English tax rates are three times as high as ours.

...

... It has been a big hole in the law. 
with higher taxes. Congress has steadfastly maintained that countries with relatively high tax rates and the taxpayers investing in them, not the United States Treasury, should bear the economic costs associated with those excessive burdens ${ }^{47}$ and, thus, that while taxpayers should not be subjected to double taxation, their total tax burden should be the higher of the tax imposed by the source country or by the Umited States. Paradoxically, though, the primary mechanism Congress utilizes to enforce that decision, the foreign tax credit limitation, ${ }^{48}$ often allows taxpayers and high-tax countries to shift the burden of higher taxes back to the United States.

The foreign tax credit limitation, as its name suggests, limits the amount of foreign tax credit that may be used by a taxpayer during a particular tax year. With minor exceptions, ${ }^{49}$ it limits the allowable credit to the amount of the taxpayer's pre-credit federal income tax liability for the year that is attributable to foreign-source income. ${ }^{50}$ This amount is determined by calculating the ratio between the taxpayer's foreign-source income and his total taxable income and then multiplying the taxpayer's total pre-credit federal income tax liability by this fraction. ${ }^{51}$ For example, if over the course of a year a taxpayer earns a total of $\$ 20,000$, his pre-credit federal income tax obligation would be $\$ 5600 .^{52}$ If $\$ 5000$ of that income is derived from foreign

47 See, e.g., S. Rep. No. 1881, supra note 8 , at 72 (revising foreign tax credit rule to "end the use of [a] device" to utilize excess foreign tax credits that is "harmful to our monetary stability and balance-of-payments position"); Staff of Joint Comm. on Tax'n, 99th Cong., 2d Sess., General Explanation of the Revenue Provisions of the Deficit Reduction Act of 1984, at 348 (Joint Comm. Print 1984) [hereinafter 1984 General Explanation] (change in source rules to prevent "pass[ing] the cost of high foreign taxes from the U.S. taxpayer to the U.S. Government"); see also The President's Tax Proposals to the Congress for Fairness, Growth, and Simplicity 387-88 (May 1985) [hereinafter President's Tax Proposals] (discussing how the reduction of U.S. corporate tax rate would increase pressure to find offsetting low-tax investments, and suggesting "per country" limitation to prevent taxpayers from transferring burden of excess foreign taxation back to United States government).

48 The general foreign tax credit limitation is contained at $\S 904$ of the Code. Section 907 of the Code provides a special limitation regime applicable to oil-related foreign source income. See I.R.C. $\S \S 904,907$ (1982 \& Supp. V 1987).

49 Most of these exceptions are related to the carryover provisions discussed infra notes 5455 and accompanying text. See also I.R.C. § 904(f) (1982 \& Supp. V 1987) (recapturing previously deducted foreign losses); id. $\$ 960$ (b) (Supp. V 1987) (increasing limitation for tax paid with respect to amounts included in income in a prior year).

so See W. Gifford \& E. Owens, 2 International Aspects of U.S. Income Taxation: Cases and Materials 99-100 (1982); R. Kaplan, supra note 5, at 106; Dale, supra note 34, at 180.

51 I.R.C. § 904(a) (Supp. V 1987).

S2 Assuming a tax rate of $28 \%$. 
sources, the taxpayer's foreign tax credit limitation would be $\$ 5600$ multiplied by $\$ 5000 / \$ 20,000$, or $\$ 1400$. The taxpayer would be allowed to claim a maximum of $\$ 1400$ of foreign tax credit against his federal income tax liability for the year, regardless of how much foreign income tax he paid during that taxable period. This result holds true whether the taxpayer's foreign source income comes from (and foreign tax payments are made to) only one foreign country or several countries, because the tax credit limitation is calculated on an "overall" basis. ${ }^{53}$

If the taxpayer described above paid $\$ 2500$ in foreign income taxes over the year, earning $\$ 2500$ of foreign tax credit, the Code allows him to carry the $\$ 1100$ of excess credit to a limited number of other taxable years, ${ }^{54}$ where it may be used to offset federal tax liabilities for those years if, and only if, allowable under those other years' foreign tax credit limitations. ${ }^{55}$ If the taxpayer is unable to use his excess tax credit during that time frame, it simply expires, ${ }^{56}$ leaving the taxpayer to absorb the cost of the excess taxes paid (and perhaps discouraging him from continuing to invest in such high-tax locales). If the taxpayer can use the excess credit to offset federal income tax liability accrued with respect to lightly taxed foreign-source income, however, the United States will absorb the cost of investing in high-tax jurisdictions by forgoing taxes it would otherwise have collected on that lightly taxed foreign income. ${ }^{57}$

Let us return to the example of the investor with $\$ 1,000,000$ to invest and analyze his behavior when facing all three of the options presented: the $6 \%$ U.S. bank, the 5\% Hong Kong bank, and the $6 \%$ German bank. If the taxpayer must deposit all his funds in one bank, it will be the U.S. bank. After all, $\$ 43,200$ is much better than $\$ 36,000$ (the Hong Kong return after payment of taxes) or $\$ 33,000$

53 That is, the tax credit limitation is calculated with reference to all foreign-source income and foreign income taxes on a combined basis, rather than being computed and applied separately for each foreign country in which the taxpayer earns income or pays taxes. The latter type of tax credit limitation is termed a "per country" limitation; for a more complete description and analysis of such a system, see infra notes 112-26 and accompanying text.

s4 See I.R.C. $\$$ 904(c) (Supp. V 1987) (allowing two year carryback and five year carryover of excess tax credits).

55 Id.

56 R. Kaplan, supra note 5, at 105.

57 See, e.g., W. Gifford \& E. Owens, supra note 50, at 100-01 (providing example); R. Hellawell \& R. Pugh, supra note 19, at 138-39 (same). 
(the German return after taxes). But if the taxpayer can split the funds between the two foreign banks-for instance, $\$ 500,000$ in the Hong Kong bank and $\$ 500,000$ in the German bank-his after-tax return increases to $\$ 39,000 .{ }^{58}$ This result occurs because the taxpayer is able to use some of the excess credit from the German investment to offset the residual U.S. tax liability from the Hong Kong investment. Still, a profit-maximizing investor would put his funds in the U.S. bank.

But suppose we change the facts slightly and assume that the German bank pays $7.5 \%$ interest. In a head-to-head competition, the U.S. bank still wins. The higher German tax more than wipes out the interest advantage; the investor's after-tax return is merely $\$ 41,250 .^{59}$ If the taxpayer now tries a fifty-fifty split, however, the U.S. bank's advantage virtually disappears. The investor's total after-tax return from the Hong Kong-German split is $\$ 43,125,{ }^{60}$ only $\$ 75$ less than the after-tax return from the domestic bank. It is easy to see that an investor who is committed or inclined to the German bank now has a positive incentive to invest other funds in Hong Kong, rather than in the United States, even though the Hong Kong bank's nominal return is less than that of the U.S. bank. By thus favoring Hong Kong investments over investments in the United States, the tax rules are quintessentially nonneutral. ${ }^{61}$

58 The taxpayer's investment in Hong Kong would yield $\$ 25,000$, less $\$ 2,500$ in taxes, while the German investment would yield $\$ 30,000$, less $\$ 13,500$ in taxes; the total return after foreign taxes is $\$ 39,000$. No U.S. taxes would be due, because the entire U.S. tax liability of $\$ 15,400$ (28\% of $\$ 55,000$ ) would be offset by the $\$ 16,000$ of available foreign tax credit. This example ignores the possibility of U.S. minimum tax liability, see supra note 37 (describing special foreign tax credit limitation for alternative minimum tax), in the interest of simplicity. Note, however, that the minimum tax obligation will occur only when the taxpayer has virtually no taxable income from U.S. sources (that is, when the taxpayer earns almost solely foreign-source income).

59 The gross receipt of $\$ 75,000$ would generate a German tax liability of $\$ 33,750$, leaving $\$ 41,250$. This sum would be the investor's after-tax return, as the tax credit generated from payment of the German tax obligation would fully offset the tentative U.S. tax liability of $\$ 21,000$.

60 The Hong Kong investment would again yield $\$ 22,500$ net of $\$ 2,500$ local tax, while the German investment would yield $\$ 20,625$ net of $\$ 16,895$ taxes, for a post-tax total of $\$ 43,125$. The combined foreign taxes of $\$ 19,395$ would more than offset the tentative U.S. tax liability of $\$ 17,500$, so no additional U.S. tax would have to be paid.

61 By providing an opportunity to offset the tax disadvantage generated by the high German tax levy, the U.S. tax rules also make the German investment more attractive to the investor. Because the investment's initial unattractiveness, however, is due to the operation of a tax system, in economic terms this effect is "neutralizing." It violates the defensive neutrality goal 
This example demonstrates the tax credit mechanism's fatal flaw. The system, which works beautifully when all foreign jurisdictions levy taxes at relatively low rates (or relatively high rates), collapses when both high- and low-rate foreign jurisdictions exist, for it allows a residence country to be whipsawed among them. Well-advised taxpayers can avoid the disincentive associated with investing in high-tax jurisdictions by making compensating investments in low-tax jurisdictions, thus regaining the neutrality the foreign tax credit limitation is meant to deny high-tax countries (and eliminating its ability to restrain source countries from taking undue advantage of U.S. investors). ${ }^{62}$ Moreover, the neutrality obtained with respect to investments in low-tax countries simultaneously disappears, for such investments are the means of achieving the desired neutrality for investments in countries with high tax rates. ${ }^{63}$ Taxpayers become more likely to invest in both high- and low-tax foreign jurisdictions! To the extent that the exported capital would have been invested in the United States absent tax considerations, our government loses twice-it loses the tax revenues that would have been collected had the investment been made within its borders, and it loses the social benefits of increased investment in the United States. Instead of providing superiority over high-tax jurisdictions and equality with low-tax jurisdictions, the tax credit mechanism ends up providing neutrality with high-tax jurisdictions and inferiority vis-a-vis low-tax jurisdictions-a result less desirable than that obtained under an exemption system. ${ }^{64}$

adopted as the U.S. standard, however, because U.S. funds subsidize Germany's ability to exact high tax levies.

62 See 1986 General Explanation, supra note 14, at 861-62.

63 Id.

64 While this result is undesirable from the standpoint of the United States Treasury, American taxpayers with foreign-source income receive a windfall. Therefore, any congressional attempt to replace the credit system with an exemption system might be expected to result in political outcry on the part of affected constituents. At least one commentator believes the outcry would be quite significant indeed. See Kingson, supra note 30 , at 1253 (attempt to change to exemption system might "cause more protest, than the section 861 regulations proposed in 1973"). But others argue that the benefit to Treasury from switching to an exemption system would be short lived. See Patrick, Simplifying the Taxation of Foreign Source Income, 30 Nat'l Tax J. 321, 324 (1987) (though switch to an exemption system could contribute to a net increase in U.S. revenues, "[i]t would also lead to tax planning" and "would put a premium upon the use of low tax foreign countries as the location for foreign subsidiaries"); Surrey, Changes in U.S. Taxation of Business Abroad: The Possible Alternatives, $32 \mathrm{~J}$. Tax'n 312, 313 (1970) ("[A]fter a while the tax results might well look quite 
The last several tax acts have tried to minimize this problem by making it harder for taxpayers to "blend" highly and lightly taxed foreign-source income in the calculation of their foreign tax credit limitation. Specifically, Congress has required taxpayers to isolate traditionally lightly taxed income, such as passive investment income, in "baskets" separate from those containing traditionally highly taxed income, such as active business income, and then to compute and apply a separate tax credit limitation for each basket. ${ }^{65}$ Moreover, Congress has rewritten several source rules in order to prevent taxpayers from inflating the numerator of the foreign tax credit limitation fraction ${ }^{66}$ with "foreign" income unlikely to be subject to any foreign tax, ${ }^{67}$ and to make it harder for taxpayers to transform income

different under the exemption approach, as its opportunities for tax escapes were pored over and tested.").

${ }^{65}$ Congress first began utilizing separate limitation baskets based on the character (rather than the source) of income in 1962, when it enacted a separate credit limitation for "passive interest income." Pugh \& Sessions, The Foreign Tax Credit Limitation: An Analysis of the President's Tax Proposals, 19 Int'l Law. 1239, 1261 (1985). See Revenue Act of 1962, Pub. L. No. 87-834, § 10, 76 Stat. 960, 1002-03 (codified at I.R.C. $\S 904$ (f) (1970), current version at I.R.C. $\S 904$ (d) (Supp. V 1987)). Congress subsequently expanded its reliance on that device, adding baskets for oil-extraction income in 1969 and 1975. See Tax Reform Act of 1969, Pub. L. No. 91-172, § 506(a), 83 Stat. 487, 634-35 (codified as amended at I.R.C. § 901(e) (1982)); Tax Reduction Act of 1975, Pub. L. No. 94-12, §601, 89 Stat. 26, 54 (codified as amended at I.R.C. $\S 907$ (1982 \& Supp. V 1987)); see also Randall, Developments in Foreign Tax Credit: How It Affects Doing Business Abroad, 37 J. Tax'n 298, 299 (1972) (reduction of creditable taxes attributable to foreign mineral income in the 1969 Act "operates as a separate limitation on these foreign taxes along the lines of [the interest limitation contained in] Section 904(f)"). Baskets were also created for income from domestic international sales corporations (“DISC's") in 1971, see Revenue Act of 1971, Pub. L. No. 92-178, § 502(b), 85 Stat. 497, 54950 (codified as amended at I.R.C. $\S 904(d)(1)(F)$ (Supp. V 1987)), and income from foreign sales corporations ("FSC's") in 1984, see Deficit Reduction Act of 1984, Pub. L. No. 98-369, $\S 801$ (d)(2), 98 Stat. 494, 995-96 (codified as amended at I.R.C. $\S 904(d)(1)(H)$ (Supp. V 1987)). The 1986 Act was unique only in the number of baskets created-it added four new baskets (for shipping income, high withholding tax interest income, financial services income, and noncontrolled foreign corporation dividend income) and expanded the reach of the interest income basket to all "passive" income. See Tax Reform Act of 1986, Pub. L. No. 99514, §§ 1201(a)-1201(d), 100 Stat. 2085, 2520-25 (codified as amended at I.R.C. § 904(d) (Supp. V 1987)).

66 The "foreign tax credit limitation fraction" is the fraction created for purposes of determining the ratio required by section 904(a), the numerator of which consists of the taxpayer's foreign-source income (or so much of that income as is permitted under an appropriate "basket") and the denominator of which is the taxpayer's worldwide income for the taxable year. See supra text accompanying note 51 .

67 See Tax Reform Act of 1986, Pub. L. No. 99-514, §1211, 100 Stat. 2085, 2533-36 (codified as amended at I.R.C. $\S \S 861-865$ (Supp. V 1987)). See also 1986 General Explanation, supra note 14 , at 918 : 
from one basket or source into income from another by interposing additional foreign entities. ${ }^{68}$

Although these reforms make it more difficult for taxpayers to "blend" income taxed at different rates, blending can still be both possible and profitable. Taxpayers willing and able to match highly taxed income-producing activities with lightly taxed income falling in the same limitation basket can achieve the felicitous results available to them under prior law. Instead of offsetting highly taxed active-business income with lightly taxed interest income, a maneuver that can be easily and cheaply accomplished by relocating liquid assets to a bank in a tax-haven country (that is, a country with low tax levies), taxpayers must offset their highly taxed active-business income with lightly taxed business income. Accordingly, instead of maintaining bank accounts in low-tax countries, taxpayers must use those funds to open stores or factories or other business enterprises in low-tax countries.

Whether the changes in the tax credit limitation rules advance or undercut Congress's objectives depends on how many taxpayers persevere to obtain advantageous blending and how many simply give up, close their foreign bank accounts-and perhaps even their highly taxed foreign business operations-and bring their capital back to the United States. Clearly, if a substantial portion choose to continue blending, the reforms will have been worse than in vain-they will have been positively detrimental. Not only would such taxpayer behavior thwart the objective of the rule changes, it also would dimin-

With regard to U.S. persons, Congress believed that, with the substantial reduction of U.S. tax rates provided in the Act, more U.S. taxpayers would have excess foreign tax credits and that, therefore, there would be more incentive after tax reform to generate low-taxed foreign source income to absorb the excess foreign tax credits. . . W With the above in mind, Congress modified prior law's source of income rules to ensure that the United States . . . will treat as foreign source income only that income which is generated within a foreign country and which is likely to be subject to foreign tax.

68 See Tax Reform Act of 1986, Pub. L. No. 99-514, $\S 1214,100$ Stat. 2085, 2541-44 (codified as amended at I.R.C. $\$ \S 861,871,881$ (Supp. V 1987)); Deficit Reduction Act of 1984, Pub. L. No. 98-369, $\S 121$ (a), 98 Stat. 494, 638-40 (codified as amended at I.R.C. $\S 904$ (g) (Supp. V 1987)); see also 1986 General Explanation, supra note 14, at 937-40 (describing changes in tax treatment of interest and dividends paid by " $80 / 20$ " companies to reverse "prior treatment [which] ... had the result of artificially inflating U.S. persons' foreign source income for foreign tax credit limitation purposes"); 1984 General Explanation, supra note 47 , at 346-49 (detailing changes made to "prevent] the conversion to foreign source income of certain U.S. source income earned through a foreign corporation"). 
ish the most cherished portion of the United States' economic base, jobs. When blending is accomplished by moving active business operations overseas, the number of jobs lost likely exceeds those lost due to blending obtained by moving a passive investment of the same amount overseas. ${ }^{69}$ If Congress is lucky, only a few taxpayers will persist in blending attempts under the new regime, but the best that can be hoped for is occasional, rather than wholesale, losses of revenue and jobs. In short, Congress has embarked on a gamble, with slightly better odds-but higher stakes-than the earlier system.

Even if successful, however, Congress's strategy cannot completely solve the whipsaw problem. The tax credit mechanism's inherent inability to cope with blending possibilities is exacerbated by another

69 Congress encountered a similar problem after the passage of the subpart $\mathrm{F}$ regime in 1962. See Revenue Act of 1962, Pub. L. No. 87-834, 76 Stat. 960, 1006-27 (codified as amended at I.R.C. $\$ \S 951-964$ (1982 \& Supp. V 1987)). Under subpart F, "United States shareholders" of a "controlled foreign corporation" are subject to current federal taxation on their proportionate shares of the corporation's "subpart F income." Cohen \& Hankin, A Decade of DISC: Genesis and Analysis, 2 Va. Tax Rev. 7, 12-13 (1982); see I.R.C. § 951(b) (1982) (definition of "United States shareholder"); id. § 957(a) (Supp. V 1987) (definition of "controlled foreign corporation"); id. \$952(a) (Supp. V 1987) (definition of "subpart F income"). This treatment can be significantly less favorable than that accorded most income derived by U.S. residents (both individuals and corporations) through foreign corporations, which escapes tax until received by the U.S. resident in the form of a dividend or gains from the sale of the foreign corporation's stock. See infra notes 74-85 and accompanying text. One group of taxpayers adversely affected by the subpart $F$ regime were U.S. exporters of American-made goods distributed through foreign "base companies." See Cohen \& Hankin, supra, at 10-11 (describing base company operations); id. at 14 (describing subpart F's effect on taxation of base company operations). Since exporters could escape subpart F's reach by moving their production facilities abroad (specifically, to the base company's country of incorporation, see I.R.C. \$ 954(d)-(e) (1982 \& Supp.V 1987)), Treasury worried that exporters were being encouraged to move their manufacturing operations overseas. See Cohen \& Hankin, supra, at 25-26. As a result, in 1969 it proposed the enactment of the DISC (domestic international sales corporation) provisions, which gave back to exporters some of the tax privileges they enjoyed prior to the adoption of the subpart F regime. Id. at 26-29 (deferral of federal taxation restored for one-quarter of export income). These provisions were finally adopted as part of the Revenue Act of 1971, Pub. L. No. 92-178, §§ 501-507, 85 Stat. 497, 53553 (codified as amended at I.R.C. $\$ \S 991-997$ (1982 \& Supp. V 1987)). When these provisions were determined to be an "export subsidy" contrary to our obligations under the General Agreement on Tariffs and Trade ("GATT") treaty, see Cohen \& Hankin, supra, at 29, Congress substituted a similar device, the "foreign sales corporation" ("FSC"), see Deficit Reduction Act of 1984, Pub. L. No. 98-369, $\$ \$ 801-805$, 98 Stat. 494, 985-1003 (codified as amended at I.R.C. $\$ \S 921-927$ (Supp. V 1987)), which, it hopes, will fulfill the same function as the DISC rules without violating our treaty obligations. See 1984 General Explanation, supra note 47, at 1041-42; Note, The Making of a Subsidy, 1984: The Tax and International Trade Implications of the Foreign Sales Corporation Legislation, 38 Stan. L. Rev. 1327, 1327-28 (1986). 
failure of the system: its inadequate response to the reality of two-tier taxation of corporate income. This failure, explained in the next Section, not only increases the number of ostensibly high-tax countries, and thus the pressure to find low-tax investment offsets, but also provides another impediment to the achievement of a "defensively neutral" tax system (that is, the self-protective variant of neutrality pursued by Congress).

\section{B. The Problem of Two-Tier Corporate Taxation}

The tax treatment of income earned abroad by American-owned foreign subsidiaries has long been the subject of considerable dispute. The usual contention has been that the tax rules treat such income too favorably, encouraging the exportation of American capital and jobs. ${ }^{70}$ Furthermore, it has been pointed out, the favorable treatment of the initial foreign investment, described presently, is accompanied by very unfavorable treatment of foreign earnings repatriated to the United States. ${ }^{71}$ As a result, not only is there an incentive to send capital abroad, but there is also an incentive to reinvest abroad all of the earnings of that capital. ${ }^{72}$ The specifics of this tax treatment are outlined below. ${ }^{73}$

Foreign subsidiaries of American corporations traditionally have been treated as foreign entities for tax purposes. As a result, only their U.S.-source income is subject to federal income tax on a current

70 See, e.g., Federal Tax Reform for 1976, supra note 8, at 77-92; P. Musgrave, supra note 8, at 161-62; Bird, supra note 28, at 295; Kingson, supra note 30, at 1269. But see Ture, Taxing Foreign-Source Income in U.S. Taxation of American Business Abroad 37, $63-66$ (American Enterprise Institute-Hoover Policy Study No. 16, 1975) (arguing that foreign earnings should be completely exempt from U.S. tax); Vogel, supra note 25 , at 80-86 (same).

71 See, e.g., Bird, supra note 28, at 295; Hartman, The Linkage of Tax Policy and Foreign Investment, Nat'1 Bureau Econ. Res. Rptr., Summer 1984, at 11, reprinted in 25 Tax Notes 1255,1256 (1984) ("[T]he U.S. corporate income tax is literally a tax on dividend payments from a foreign subsidiary to the U.S. parent.").

72 See Bird, supra note 28, at 295; Hartman, Deferral of Taxes on Foreign Source Income, 30 Nat'1 Tax J. 457, 457 \& 461 n.1 (1977).

73 The discussion in this Part of the Article relates for the most part to problems arising from the taxation of foreign corporations owned or partially owned by American corporations. Similar problems arise with respect to foreign corporations owned by American individuals. In the interest of avoiding confusion (especially given the relative scarcity of such situations), the text of this Article ignores the individual U.S. shareholder alternative; however, the footnotes attempt to elucidate the taxing regime applicable to individual U.S. shareholders, as well as the problems it creates. 
basis. ${ }^{74}$ Federal income tax is levied on their foreign-source income when and if such income is realized by the American parent corporation. Realization events that trigger the imposition of this "catch-up" tax include the receipt of either a dividend distribution or proceeds from the sale of the foreign subsidiary's shares. ${ }^{75}$ Until the occurrence of such an event, the foreign earnings of a foreign subsidiary, even one owned entirely by U.S. shareholders, are subject only to foreign income tax. ${ }^{76}$

When a foreign corporation pays a dividend to a U.S. shareholder, the shareholder must include the dividend amount in the shareholder's U.S. taxable income. ${ }^{77}$ This inclusion is required even if the shareholder is a corporation $;^{78}$ indeed, in addition to the amount of the dividend itself, parent corporations ${ }^{79}$ must include as income an amount corresponding to the foreign income taxes paid by the subsidiary with respect to the dividend amount. ${ }^{80}$ The parent corporation is then allowed to claim a tax credit against the resulting U.S. income tax liability for whatever foreign income taxes it has itself paid with

74 I.R.C. $\$ \S 881-882$ (1982 \& Supp. V 1987); P. McDaniel \& H. Ault, supra note 32, at 39. This general principle is overcome under some special statutory regimes, such as subpart $F$, see supra note 69 , applicable to certain income derived by controlled foreign corporations; the foreign personal holding company rules, I.R.C. $§ 551-558$ (1982 \& Supp. V 1987), applicable to passive income earned by closely held corporations; and the passive foreign investment company rules, I.R.C. $\$ \S 1291-1297$ (Supp. V 1987), applicable to foreign corporations earning mostly passive income. All of the above exceptions impose current U.S. income taxation on some items of foreign-source income earned by the affected taxpayers. See $R$. Kaplan, supra note 5, at $216,284-85$. For the most part, the reach of these special regimes has been circumscribed to avoid affecting income generated by active business activities undertaken outside the United States. See 1986 General Explanation, supra note 14, at 973 (describing congressional efforts to limit effects of subpart $F$ on "U.S. taxpayers using foreign corporations for business rather than tax reasons").

751986 General Explanation, supra note 14, at 962-63.

76 W. Gifford \& E. Owens, supra note 50 , at 7-8.

77 I.R.C. $\$ 61(\mathrm{a})(7)(1982)$.

78 The dividends-received deduction normally available under $\S 243$ applies to dividends received from "domestic corporation[s]," I.R.C. \$ 243(a) (Supp. V 1987), while the deduction applicable to dividends received from foreign corporations is limited to the extent that the dividend received is attributable to U.S.-source income. See I.R.C. § 245(a)(1) (Supp. V 1987).

79 The term "parent corporation" is used herein to refer to any U.S. corporation that owns at least $10 \%$ of the shares of a foreign corporate "subsidiary." This is the degree of ownership required to qualify for a "deemed-paid credit" under $\S 902$. See I.R.C. $\S 902$ (a) (Supp. IV 1986). The Code's definition thus allows a foreign corporation to have more than one U.S. "parent."

80 Id. $\S 78$ (1982). The parent's income is required to be "grossed up" by the amount of this tax. 
respect to the dividend, ${ }^{81}$ and also for the foreign taxes paid by the foreign subsidiary-which are "deemed paid" by the parent-with respect to the amount distributed. ${ }^{82}$ The parent corporation's U.S. tax liability for a dividend distribution thus consists of the difference between the U.S. tax assessed and the foreign tax payments previously made with respect to the pre-tax foreign earnings associated with the dividend. Depending on the level of foreign taxation, the resulting federal tax liability may be great or nonexistent. The higher the U.S. tax liability (or, to put it another way, the lower the foreign tax rate), the more reluctant the U.S. parent becomes to have the foreign subsidiary declare a dividend. This reluctance stems from the fact that deferring the catch-up federal tax is profitable; it enables the taxpayer to continue to use the deferred tax money to earn profits for itself, thus decreasing the economic burden of the tax that is eventually paid. ${ }^{83}$ In short, U.S. investors operating in low-tax countries through foreign subsidiaries enjoy a lower effective rate of taxation on their foreign income than comparable U.S. investors operating domestically ${ }^{84}$ - and the tax advantage continues to grow as long as the investor avoids receiving dividends. ${ }^{85}$

Prior to the passage of the Tax Reform Act of 1986, some taxpayers could magnify the tax advantages of deferral by realizing their foreign subsidiaries' earnings either through the sale of the subsidiaries' shares or in the form of liquidating distributions, rather than

81 Id. $§ 901$ (1982 \& Supp. V 1987).

82 Section 902 treats foreign income taxes paid by foreign subsidiaries with respect to amounts distributed as dividends as being paid ("deemed paid") by a U.S. corporation for purposes of determining the amount of foreign tax credit available to that corporation under $\$ 901$, provided that the corporation (and any intervening corporations, in the case of distributions attributable to profits earned by second- and third-tier subsidiaries) meets certain ownership requirements. Id. $\$ 902$ (Supp. V 1987).

83 See Hartman, supra note 72 , at 457 ("[T]axes to be paid in the future have a lower present value to both the firms and the government."). The same deferral advantages are available to individual shareholders of foreign corporations; indeed, as such shareholders are ineligible for the deemed-paid credit, the federal catch-up tax triggered by the distribution is likely to be higher, and the disincentive to receive such distributions accordingly greater.

84 See, e.g., W. Gifford \& E. Owens, supra note 50, at 129-30 (demonstrating rate reduction through numerical examples); P. McDaniel \& H. Ault, supra note 32, at 127 ("[D]eferral of tax gives a higher after-tax rate of return to operations undertaken through a foreign subsidiary than that available to the other forms of operation ....").

85 The longer the realization event (the dividend) is postponed, the more time the investor has to invest the deferred tax amount at a profit, and, if the investment is a good one, the more profits can be generated. 
through the receipt of ordinary dividends. Gains reatized through sales of stock or upon a corporation's liquidation were typically treated as capital gains, ${ }^{86}$ which were subject to federal income tax at reduced rates. ${ }^{87}$ The advantage of these lower tax rates for corporate parents ${ }^{88}$ could be offset by an accompanying tax disadvantage- - the "deemed-paid" credit for foreign income taxes paid by the foreign subsidiary cannot be used to satisfy the capital gains tax, as it does the ordinary income tax. ${ }^{89}$ In a world where capital gains were taxed at $28 \%$ rather than $46 \%$, however, the total tax burden on foreign capital gains was lighter than that imposed on gains repatriated in the form of ordinary dividends whenever the subsidiary's effective foreign tax rate was less than $25 \% .^{90}$ Now that the capital gains rate has been raised to the saine as that imposed on ordmary income, it is never to a taxpayer's advantage to realize foreign gains through the sale of a subsidiary's stock; the availability of the deemed-paid tax credit clearly favors dividend distributions. This is not to say that such sales are always disadvantageous; if the foreign subsidiary pays no foreign taxes, or if the Code treats gains from the sale of a subsidiary's shares as ordinary dividend income, ${ }^{91}$ the overall tax treatment of such gains

86 See I.R.C. $\S \S 331(a)(1), 1221$ (1982).

87 Corporations could elect to have their capital gains taxed at a $28 \%$ rate, see id. $\$ 1201$ (a), rather than under the normal rate schedule, which had a top marginal rate of $46 \%$. See id. $\S 11(\mathrm{~b})$. Individuals were allowed to deduct $60 \%$ of their "net capital gain" from gross income, see id. $\S 1202$, so that the tax imposed on capital gains income was only $40 \%$ of the tax imposed on equivalent amounts of dividend income.

88 As individual shareholders are never entitled to a deemed-paid credit, they are unaffected by its loss. See I.R.C. $\S$ 902(a) (Supp. V 1987).

89 The deemed-paid, or indirect, credit applies by its terms only when a domestic corporation "receives dividends" from a foreign corporation. Id. Amounts received by a parent corporation upon the sale of a subsidiary's stock generally are not considered the equivalent of dividends for this purpose, even though they can be viewed as simply another method of collecting the same economic gain. See W. Gifford \& E. Owens, supra note 50, at 80-81; P. McDaniel \& H. Ault, supra note 32, at 87 \& n.15. However, a number of statutory exceptions to this general rule exist. See infra note 91 .

90 See 1 E. Owens \& G. Ball, The Indirect Credit: A Study of Various Foreign Tax Credits Granted to Domestic Shareholders Under U.S. Income Tax Law § 3/3A, at 206-08 (1975) (deriving formula for determining when repatriation in capital gain form is preferable to dividend distribution; finding capital gains treatment advantageous up to an effective foreign tax rate of $25.7 \%$ when U.S. regular corporate tax rate of $48 \%$, and capital gains rate is $30 \%$ ).

91 See 1986 General Explanation, supra note 14, at 1022 (describing history of and policy behind I.R.C. $\$ \S 1246,1248$ (Supp. V 1987), which treat certain gains from the disposition of shares of foreign corporations as dividends); W. Gifford \& E. Owens, supra note 50, at 80-81 (listing corporate dispositions and transactions that by statutory proviso result in ordinary dividend income rather than capital gains). 
will approximate those of dividend distributions.

In sum, this taxing scheme allows American corporations ${ }^{92}$ doing business in low-tax jurisdictions abroad the opportunity to reap significant tax advantages over competitors located in the United States. Exactly how significant the advantage will be depends on the rate of foreign tax paid and the length of the deferral period. But as long as opportunities for such benefits exist, corporations can be expected both to send more money abroad, and to reinvest abroad more of the earnings derived from that money, than they would absent tax considerations. The scheme is thus quintessentially nonneutral.

The catch-up federal tax liability described above is not the only tax liability triggered by a foreign subsidiary's payment of a dividend to a U.S. parent. Almost invariably, such dividends are subjected to source-country income tax as well, even though the foreign corporation may have already paid a full source-country income tax on the profits being distributed. ${ }^{93}$ That such foreign taxation occurs is hardly surprising; it is reminiscent of our own two-tier tax system, which levies one tax at the corporate level and another at the individual shareholder level. ${ }^{94}$ Under such a two-tier tax system, the distribution of a dividend typically provides the occasion for the imposition of the second, shareholder-level tax. To avoid or minimize multiple

92 Whether U.S. individuals glean a tax advantage from engaging in business abroad through a foreign corporation depends on whether the alternative is to carry on U.S. business activities personally or through an American corporation. In comparison with the taxation of activities carried out personally in the United States, the imposition of any foreign corporatelevel tax leaves the taxpayer relatively worse off. Compared to the taxation of activities undertaken in the United States in the corporate form, however, the taxpayer benefits whenever the foreign corporate tax levy is less than the corresponding U.S. levy. In either case, once a U.S. individual has begun engaging in activities through a foreign corporate entity, an incentive to reinvest foreign earnings abroad develops.

93 See Blum, How the United States Should Tax Foreign Shareholders, 7 Va. Tax Rev. 583, 595 (1988) (U.S. practice of levying withholding tax on gross dividends paid to foreign persons "consistent with the practices of other countries"); see also Federal Income Tax Project, supra note 20, at 62-63 ("laws of many countries" consider source of dividends to be the "country of the distributing corporation's domicile," though an "alternative point of view focuses on the country in which the corporation has generated the earnings out of which the dividend distribution is made").

94 A country does not have to subscribe to a "classical" two-tier tax system, however, to justify the imposition of a second-tier shareholder tax; such a tax is equally consistent with a one-level integrated tax system or a split-rate system. See J.D.R. Adams \& J. Whalley, supra note 23, at 11-16 (describing different systems of corporate taxation); id. at 55-58 (describing taxation of multinationals under each system of taxation); Kingson, supra note 30, at 1195-97 (same). 
impositions of this second-tier tax-that is, triple and quadruple taxation-when complex corporate structures are involved, our domestic law postpones the imposition of the shareholder-level tax by allowing a dividends-received deduction whenever the dividend recipient is another domestic corporation. ${ }^{95}$ No such postponement is allowed in the case of foreign corporate shareholders, ${ }^{96}$ however, for a very simple reason: The individual shareholders ultimately receiving the benefit of such distributions typically reside outside of our taxing jurisdiction. Thus, unless a second-tier "withholding"97 tax is levied against the first foreign dividend recipient, whether a corporation or an individual, it is likely never to be collectible. ${ }^{98}$ It is hardly surprising that other countries have reached the same conclusion and made similar adjustments in their tax rules.

Considering the benefits (beyond additional tax revenues) that accrue to a source country from the imposition of a premature ${ }^{99}$ second-tier tax, this statutory norm is even less surprising. While the withholding tax, by further discouraging U.S. parent corporations from having their foreign subsidiaries declare dividends, operates to

95 I.R.C. $\S 243$ (Supp. V 1987) (allowing $70 \%$ or 100\% "dividends-received" deduction, depending on percentage of distributing corporation owned by recipient corporation); see Blum, supra note 93, at 601 ("In a domestic context, a dividends-received deduction is permitted to a corporate shareholder to avoid multiple layers of United States corporate tax; the shareholder-level tax is imposed on dividends paid by the corporate shareholder to its individual shareholders.").

96 Foreign corporate shareholders may not take advantage of $\S 243$ because their dividend income from U.S. sources is taxed on a gross income basis. Blum, supra note 93 , at 594. See I.R.C. $\$ 881(\mathrm{a})(1)$ (Supp. V 1987) (levying 30\% tax on dividends received by foreign corporation from U.S. sources); id. $\S 882(\mathrm{c})(1)(\mathrm{A})$ (1982) (limiting foreign corporations' use of deductions to income "effectively connected with the conduct of a trade or business within the United States," which is taxable at normal graduated rates).

97 Such shareholder-level taxation is enforced by requiring the dividend payor to withhold the amount of the levy and to tender this amount to the source-country treasury. See I.R.C. $\S \S 1441-1442$ (1982 \& Supp. V 1987) (imposing withholding obligations on payments made by U.S. businesses to foreign individuals and corporations). Thus, the real "payor" of the tax is the local subsidiary, over which the source country has considerable control.

98 See Blum, supra note 93 , at $602 \&$ nn.76-77 (withholding tax viewed as a substitute for a U.S. tax on the dividends ultimately paid by the foreign corporation to its foreign individual shareholders). The United States' inability to collect a second-tier tax from foreign taxpayers impelled Congress, as part of the 1986 Act, to enact a "branch tax," which imposes a similar levy on the U.S. profits of branch operations of foreign corporations remittable to the foreign home office. See 1986 General Explanation, supra note 14, at 1036-37.

99 This tax levy is not "premature" when it is imposed on U.S. individuals receiving dividend distributions; it corresponds exactly to the U.S. treatment of dividends received by individuals. 
the detriment of the United States in its capacity as a residence country, the tax has the opposite effect for source states. By encouraging the reinvestment of earnings in those countries, such second-tier taxes build up their economies and boost future tax collections. ${ }^{100}$ In short, source countries like the imposition of a second-tier tax for precisely the same reasons that residence countries do not. ${ }^{101}$

More surprising is the fact that, despite its expressed desire to eliminate tax incentives for the exportation of American capital, Congress has consistently ignored the effect of second-tier foreign taxes. Nowhere is this blindness more evident than in the operation of the foreign tax credit rules. Although the American parent is allowed to claim a credit for the foreign withholding tax, as it may for the foreign income taxes paid by its subsidiary, the credit generated by payment of this second-tier tax may be utilized only to offset the first-tier (corporate) federal income tax imposed with respect to the foreign-generated income. ${ }^{102}$ At best, then, by merely effecting a transfer of catchup tax revenues from the United States to the foreign source country, ${ }^{103}$ such withholding taxes mimic the incentive for reinvestment

100 Of course, to the extent that the second-tier foreign tax is not (or is not expected to be) creditable against the U.S. catch-up tax (because, for example, total foreign taxes exceed the foreign tax credit limitation), its presence may convince U.S. investors deciding between investments in a foreign country and in the United States to invest in the United States, where the tax burden will be lower in the long run. Thus, excessive second-tier source-country taxes will redound to the benefit of the residence country with respect to new investments and investors; however, when the question is whether to reinvest earnings of capital already exported to the source country, second-tier taxes generally redound to the benefit of source, not residence, countries. See generally infra note 105 (discussing the advantages of reinvestment abroad as compared to repatriation).

101 See U.N. Centre on Transnat'l Corps., supra note 29, at 21-22 (explaining and demonstrating advantages to both transnational corporations and developing countries of a tax "system of low corporate income taxes and fairly high withholding taxes" as opposed to one with high corporate income tax rates and low withholding taxes; the latter "destroy[s] the benefits otherwise available from tax deferral" while the former "would allow the transnational corporations to accumulate income in a foreign subsidiary ... subject only to the fairly low source taxes until the income was remitted ... to the United States parent company ... [and] sets up an incentive for transnational corporations to reinvest their profits in the developing countries").

102 See I.R.C. $\$$ 901(a) (Supp. V 1987) (credit granted only against taxes of taxpayer paying or deemed paying the foreign tax).

${ }^{103}$ If the source jurisdiction has a low enough corporate income tax rate, its withholding tax generates additional foreign tax credit that the American parent company may use to offset its U.S. tax obligation triggered by the same dividend distribution; in a very real sense, then, all the withholding tax does is transfer the amount of the catch-up tax from the United States Treasury to the source country. See P. Musgrave, supra note 8 , at 94 ; Kingson, supra note 30 , 
abroad otherwise provided by the catch-up tax. Thus, though the United States loses additional tax revenues to the source country, it does not lose additional investments because of the foreign withholding tax. If the subsidiary's foreign corporate income taxes with respect to the dividend, combined with the parent's withholding taxes, exceed the U.S. corporate-level income tax, however, the parent will be unable to utilize all of the credit generated by the second-tier taxunless, of course, the parent had previously availed itself of the selfhelp opportunities described in the first part of this Article. ${ }^{104}$ The United States loses either way. Either the parent becomes loath to have the subsidiary distribute dividends, which means that the subsidiary's profits are reinvested overseas rather than in the United States, ${ }^{105}$ or the parent makes excessive investments in low-tax foreign

at 1160 . Because the tax credit is available, the withholding tax does not impose an additional financial burder on the investor. See U.N. Centre on Transnat'l Corps., supra note 29, at 21 ("[S] uch taxes are set off against the foreign tax credit in the residence country.").

104 See supra notes 57-62 and accompanying text.

105 One might suspect that corporate managers would have the opposite reaction, that is, to remove as much investment from the high-tax locale as possible, just as they are dissuaded from making new investments in high-tax countries. See supra note 100 . After all, any profits derived from earnings reinvested abroad will be subjected to tax at higher-than-U.S. rates in the event they are repatriated, whereas, if the earnings are repatriated immediately, the profits derived therefrom will be subject only to U.S. tax. See Hartman, supra note 71, at 1256 ("[A]n increase in the rate of [dividend] tax on foreign-source income provides neither a disincentive to foreign investment ... nor an incentive to foreign investment [because] . . the "disincentive to invest abroad' and the 'incentive to reinvest abroad' . . . balance exactly.").

However, that analysis overlooks several possibilities. First, if the U.S. parent repatriates all of its foreign subsidiary's earnings through a liquidation or a sale of the subsidiary's shares, the parent may escape the foreign second-level tax altogether. Many countries (including, with the exception of certain real estate interests, the United States) do not tax foreigners' capital gains, at least to the extent unrelated to the taxpayers' conduct of a trade or business in their country. See Blum, supra note 93, at 617-18. But see id. at $650 \mathrm{n} .219$ (listing exceptions). To the extent that the proceeds of such sales or distributions are treated as the equivalent of dividends for U.S. tax purposes, see supra note 91 and accompanying text, deferring repatriation until a liquidation or sale is the most desirable alternative from a tax standpoint. Second, many managers may simply desire to postpone the inevitable, hoping for some favorable change to take place. See Carroll, supra note 8 , at 76,118 . Finally, of course, the managers may simply pursue their own interests-maximizing the size of the corporation by deferring payment of taxes-at the expense of the shareholders' interest in maximizing the amount of post-tax dollars eventually available for distribution as dividends. See Stone, supra note 8, at 565 . Particularly if the deferred foreign tax obligation is not reflected on the firm's balance sheet or income statement, it would take an unusually sophisticated shareholder to perceive the conflict in interest. 
countries as a matter of course. ${ }^{106}$ In both cases, the tax system generates nonneutrality and the United States ends up with less domestic investment than it would have in a tax-neutral world. ${ }^{107}$

In sum, in many relevant respects, the tax credit system has backfired. Rather than making investment in the United States competitive with investment in low-tax jurisdictions and superior to investment in high-tax jurisdictions, the system often fails to penalize investment in high-tax jurisdictions and encourages investment in low-tax jurisdictions. Moreover, whether the foreign jurisdiction has comparable, higher, or lower tax rates, distributions of accrued profits are discouraged. We seem to have the worst of all worlds rather than the best. The question for the next Part is what we can do to make the system work better.

\section{Paths to NeUtrality}

As Part I of this Article makes clear, the tax system's failure to achieve "defensive" neutrality - that is, neutrality absent subsidization of high-tax jurisdictions-springs not merely from one, but from two, causes. One is the linkage between investments in high- and lowtax jurisdictions created by the operation of the foreign tax credit limitation. The other is the disincentive for the repatriation of dividends that results from the imposition of either a catch-up federal tax or a second-tier foreign tax. The achievement of defensive neutrality thus requires a solution that resolves both of these problems simultaneously. As the following discussion shows, reaching either goal will be difficult; obtaining both simultaneously-that is, achieving defensive neutrality-may well be impossible.

\section{A. Eliminating Linkage}

One way to eliminate linkage, the whipsaw problem discussed in Part IA, ${ }^{108}$ is, of course, to eliminate the foreign tax credit limitation.

106 Dividends from these low-tax investments may then be distributed as necessary to "soak up" excess foreign tax credit from high-tax investments, much as the Hong Kong interest income soaked up the excess foreign tax credit created with respect to the German interest income in the examples provided supra notes 58-61 and accompanying text.

107 That is, under a regime of "defensive" neutrality. It is not clear that the present tax rules encourage more exportation of U.S. capital than a truly "capital export neutral" tax system would. See infra notes 108-11 and accompanying text.

108 See supra notes $41-69$ and accompanying text. 
In the absence of a limitation, taxpayers would derive no tax advantage from investing in low-tax jurisdictions. ${ }^{109}$ The exploitative power that such a course would offer source countries, however, renders this alternative impracticable. ${ }^{110}$ Furthermore, eliminating the limitation would make investments in high-tax countries generally more attractive than they are now. Not all taxpayers are willing or able to blend rates sufficiently to eliminate the economic burden of excessive foreign taxation; accordingly, some putative investment in high-tax countries must already be deterred under the present rules. This deterrence would be lost if the limitation were repealed. ${ }^{111}$

From a revenue and investment standpoint, the best solution to the linkage problem would be one that did what Congress intended the foreign tax credit limitation to do: force high-tax jurisdictions to bear the costs of their higher taxes and impose an equalizing tax on profits generated in low-tax jurisdictions. Unfortunately, it is easier to state this solution than to come up with a mechanism that achieves it.

One frequently proffered approach is the substitution of a "per country" tax credit limitation for our present "overall" limitation. ${ }^{112}$ Use of a "per country" limitation would not be novel, even for the United States; the Code relied at least in part on such a limitation in the period between 1932 and 1976. ${ }^{113}$

Under a "per country" limitation, a taxpayer would be able to utilize the credit generated by payment of one country's income tax only against U.S. tax obligations incurred with respect to income derived in that same country. ${ }^{114}$ If, for example, a taxpayer pays U.K. taxes of $\$ 500$ on $\$ 1000$ of income earned in Britain, the $\$ 160$ of excess

109 Because the taxpayer would be able to use excess credit against other U.S. income, there would be no need to seek out lightly taxed foreign investments against which this credit could be offset.

110 See supra notes $43-45$ and accompanying text.

111 Although the flow of investment to high-tax jurisdictions caused by repeal of the credit limitation may not be greater than the amount of capital repatriated from low-tax jurisdictions, such expatriation would certainly decrease the net benefit of the repeal.

112 Indeed, President Reagan's initial tax reform proposal included this change. See President's Tax Proposals, supra note 47, at 389. However, Congress decided to strengthen the system of income "baskets" based on type of income, rather than adopt a per-country limitation system. See 1986 General Explanation, supra note 14, at 862-63.

113 See Federal Income Tax Project, supra note 20, at 318; Dale, supra note 34, at 179-80.

114 See Federal Income Tax Project, supra note 20, at 321; Dale, supra note 34, at 180. 
credit $^{115}$ could not be used to offset the equalizing tax imposed on lightly taxed income from Hong Kong. It could, however, be used to offset an equalizing tax imposed on lightly taxed income from Britain, and therein lies a problem.

It has often been noted that effective tax rates vary as much among income-producing activities within most countries as they do between different countries. ${ }^{116}$ The United States is a perfect example of this phenomenon. Despite the existence of only one statutory rate applicable to all taxpayers in each income bracket, various subsidiary provisions in our tax laws have disparate effects on different taxpayers, resulting in a considerable amount of "horizontal inequality." Conceivably, taxpayers could take advantage of such disparities to achieve blending within a single country by matching investments in relatively high-tax activities with counterbalancing investments in relatively low-tax activities. ${ }^{118}$ Source countries may well be amenable (and helpful) to these efforts, especially if the low-tax matching investments could be directed toward activities that would not otherwise be undertaken in that country. ${ }^{119}$ To protect against this sort of manipu-

115 Excess credit of $\$ 160$ would result if the taxpayer's average tax rate approximated the maximum marginal corporate rate of $34 \%$, because $34 \%$ of $\$ 1000$ is $\$ 340$, which is $\$ 160$ less than the $\$ 500$ in British taxes paid. If the taxpayer's effective tax rate is less than $34 \%$, of course, the taxpayer would have an even larger excess credit.

116 See, e.g., Hartman, supra note 71, at 1257 .

117 Though the Tax Reform Act of 1986 was intended to, and did, lessen differences between firms' effective tax rates, a recent study shows that substantial variations remain. See Gray, 1986 Act Increased Effective Corporate Tax Rates, CTJ Says, 40 Tax Notes 1343, 1343 (1988) (Citizens for Tax Justice study shows average effective tax rate for American corporations in 1987 was $22.1 \%$, but 51 of 250 companies surveyed had an effective tax rate of less than 10\%).

118 See Federal Income Tax Project, supra note 20, at 324. Indeed, it was precisely the specter of such intracountry balancing that led Congress to establish the first separate "basket" in the foreign tax credit limitation. See S. Rep. No. 1881, supra note 8, at 72.

119 Many countries (including the United States) have a long history of utilizing tax incentives to attract foreign investors. See, e.g., S. Rep. No. 1881, supra note 8 , at 72 (Canada); 1984 General Explanation, supra note 47, at 348 (United States); Guttman, Despite Thirty Years of Incentives, Ireland Struggles for an Industrial Identity, 41 Tax Notes 1019, 1021 (1988) (Great Britain, Germany, the Netherlands, Northern Ireland); Jenks, supra note 8, at 548 (Ireland, Singapore, Great Britain, Italy). Though many economists argue that the wide availability of such incentives, like those offered by states and municipalities to attract development, means that they have little overall impact, see U.N. Centre on Transnat'1 Corps., supra note 29 , at 18 (tax incentives "widely regarded as ineffective in attracting foreign investment"); Surrey, The United States Taxation of Foreign Income, 1 J.L. \& Econ. 72, 89-90 (1958) (questioning advantage of tax incentives once all nations have adopted them), no country wants to be the exception to the rule. See Note, United States Tax Treaty Policy 
lation, the "per country" limitation could be further broken down among income categories, using the present law's basket approach. ${ }^{120}$ Moreover, a system of "pass-through" rules regarding the source of income, comparable to the rules recently enacted covering the characterization of income, ${ }^{121}$ could (and probably would have to) be enacted to prevent taxpayers from changing the source of income by merely passing it through intermediary entities located in favorable jurisdictions. ${ }^{122}$

All of these protections, necessary for an effective "per country" limitation, would add to the complexity of an already complex limitation system, as they would require taxpayers earning income abroad to make numerous computations and difficult allocations of income and expense items. ${ }^{123}$ As the present rules for making such allocations are uncertain at best, ${ }^{124}$ the allocation process itself is already a

Toward Developing Countries: The China Example, 35 UCLA L. Rev 369, 379 n.54 (1987) (absence of "tax sparing" treaty provisions puts nations without them at disadvantage vis-a-vis nations with such agreements).

120 See supra note 65 .

121 See supra note 68 .

122 See Federal Income Tax Project, supra note 20, at 324-26; see also Surrey, supra note 8, at $825 \mathrm{n} .19$ (explaining how use of intermediary holding company allows taxpayer to average foreign taxes and foreign income and thereby convert the per-country limitation into an overall limitation).

123 See Federal Income Tax Project, supra note 20, at 324. By the time these amendments are made to the per country limitation, it would be close to the theoretical "ideal," an item-byitem limitation.

124 According to the present rules, income and deduction items are to be allocated between U.S. and foreign sources as they would be if the domestic and foreign business entities were dealing at arm's length. See Treas. Reg. $\S 1.482-1$ (b)(1) (1988). However, many of the transfers and transactions that take place between parts of internationally integrated business entities have no arm's-length counterpart. As a result, both taxpayers and the Internal Revenue Service have to rely on less accurate, and frequently manipulable, methods for determining price and income allocations. See, e.g., Eli Lilly \& Co. v. Commissioner, 856 F.2d 855,872 (7th Cir. 1988) (approving Tax Court's use of "inherently imprecise" profit split method to allocate income between drug manufacturer and its subsidiary when taxpayer "made no definitive showing that its allocations of Darvon income mimicked arm's length transactions" ); Comptroller General of the United States, Report to the Chairman, House Comm. on Ways and Means: IRS Could Better Protect U.S. Tax Interests in Determining the Income of Multinational Corporations, GGD-81-81, at ii (G.A.O. 1981) (only 3\% of section 482 adjustments to returns of 519 multinational corporations based upon a true arm's-length price); 1986 General Explanation, supra note 14, at 1014 ("A recurrent problem is the absence of comparable arm's length transactions between unrelated parties, and the inconsistent results of attempting to impose an arm's length concept."); U.N. Centre on Transnat'l Corps., supra note 29 , at $76-78$ (process of arriving at arm's-length price "difficult, time consuming and expensive and yields ... an imprecise result"). 
target for strategic misbehavior on the part of taxpayers. ${ }^{125}$ Catching and remedying this type of misbehavior has proven extremely difficult and expensive. ${ }^{126}$ Many taxpayers may similarly be able to undercut the effect of a reinforced tax credit limitation by inventing more creative bookkeeping methods. In short, it may well be impossible to reform the macroprinciples of the international tax rules until we have a far better grip on the microprinciples, embodied in the accounting rules.

Even if we could solve the numerous and difficult accounting problems, however, another problem would remain. An attempt to solve the linkage problem by enhancing the foreign tax credit limitation would undoubtedly exacerbate the problem of two-tier taxation described in Part IB of this Article. ${ }^{127}$ The two-tier tax problem would be exacerbated because, as it becomes more difficult for taxpayers to utilize the excess tax credit generated by shareholder-level for-

125 Indeed, some of the most time-honored methods of tax avoidance and evasion in the international sphere involve the manipulation of transfer prices (the prices at which one entity sells supplies, technology, half-finished goods, or finished goods to a related entity located in another taxing jurisdiction) and the allocation of expenses. See, e.g., 1921 Hearings, supra note 46, at 262 (discussion between Dr. Adams and Sen. McCumber about how foreigners engaged in business in the United States avoided U.S. income tax by disguising profits as deductible interest); R. Kaplan, supra note 5, at 166 ("Control of intercompany transfer pricing is an enforcement problem throughout the world."). Though both Congress and the Treasury have tried to police the problem, most commentators believe that such efforts have been largely unavailing. See, e.g., Bird, supra note 28, at 298 (present methods for allocating income and expense items "produce fair, acceptable, and efficient results only by chance"); Coffill, Differences in Productivity and Profitability: A Response to Allegations of the Misattribution of Income in the Application of California's Worldwide Unitary Method, 5 Int'l Tax \& Bus. Law. 246, 271-73 (1987) (recounting criticism of effectiveness of $\S 482$ ); Wheeler, An Academic Look at Transfer Pricing in a Global Economy, 40 Tax Notes 87, 95 (1988) ("It is difficult to look at the results shown in this paper and not be concerned with the integrity of the income tax system as to transfer pricing."). A growing number of commentators believe that the task of accurately apportioning income and expenses between taxing jurisdictions is impossible and that reliance on an obviously arbitrary formulary apportionment method is both inevitable and desirable. See, e.g., Bird, supra note 28 , at 298 99; Langbein, The Unitary Method and the Myth of Arm's Length, 30 Tax Notes 625, 627 (1986). Indeed, one attraction of a "nationally neutral" system for taxing foreign income, under which foreign income taxes would be deductible rather than creditable, is that it would largely eliminate these allocation concerns.

126 See U.N. Centre on Transnat'l Corps., supra note 29, at 76; Kauder, International Allocations of Income: Problems of Administration and Compliance, 9 J. Int'1 L. \& Econ. 1, 26-27 (1974); Note, Multinational Corporations and Income Allocation Under Section 482 of the Internal Revenue Code, 89 Harv. L. Rev. 1202, 1219-21 (1976).

127 See supra notes 70-107 and accompanying text. 
eign taxes, the disincentive to repatriate profits increases. The additional steps that must be taken to eliminate the two-tier problem are discussed in the next Section.

\section{B. Eliminating the Problem of Two-Tier Taxation}

The two-tier problem is the discouragement of dividend distributions, attributable to the imposition of additional tax levies at the time of such distributions. Briefly stated, taxpayers often choose to forgo dividend distributions rather than pay the associated taxes. Because two different types of taxes may be levied at this time, a federal catchup tax and a foreign shareholder-level tax, two different corrections would be required to eliminate the problem. Each of these remedies is discussed below.

\section{Eliminating the Disincentive Effect of the Federal Catch-Up Tax}

Because dividends paid by foreign corporations to American residents trigger the federal "catch-up" tax, U.S. investors seeking the benefits of tax deferral would rather reinvest abroad than repatriate their foreign capital in the form of dividends. The simplest way to eliminate the disincentive for repatriation caused by the catch-up tax would be simply to eliminate the tax-that is, to exclude from the taxable income of U.S. corporations dividends received from foreign subsidiaries, just as dividends received from wholly-owned domestic subsidiaries are excluded under current law. ${ }^{128}$ Entirely eliminating the catch-up tax, however, would hardly advance the goal of defensive neutrality; indeed, it would merely substitute one problem for another. By excluding an entire category of foreign-source income from taxation, the elimination of the catch-up tax would transform our tax credit regime into an exemption system (at least insofar as dividend distributions are concerned). As explained in Part I, an exemption system provides investors with a financial incentive to invest in low-tax countries by allowing them to glean a higher aftertax return from the same pre-tax profit. ${ }^{129}$ Thus, as under present law, U.S. investors would have an incentive both to invest and rein-

128 See I.R.C. $\$ 243$ (1982 \& Supp. V 1987); see also supra note 95 (describing “dividendsreceived" deduction). Technically, such dividends are included in income, then deducted, resulting in their exclusion from income.

129 See supra notes $25-30$ and accompanying text. 
vest in low-tax countries abroad rather than in the United States. In fact, the financial incentive for some short-term overseas investments would be greater under a system redesigned this way. Investors unwilling to leave funds overseas for an extended time period, who would not reap much of an economic bonus from deferral, might well be tempted to invest overseas if granted a permanent, immediate tax bonus for doing so. In short, the elimination of the incentive provided by the catch-up tax to reinvest foreign profits overseas would be replaced by an incentive to increase investments in low-tax jurisdictions in the first instance. In terms of defensive neutrality, the net result of this new incentive could well be worse than the effect of the catch-up tax.

In short, a catch-up tax is necessary for the achievement of defensive neutrality; however, it must be levied in a way that does not discourage U.S. parent corporations from repatriating dividends from their foreign subsidiaries. This can be accomplished by levying the catch-up tax on both distributed and undistributed foreign profits in the year such profits are earned by the foreign subsidiary. A catch-up tax levied on the earnings of foreign subsidiaries at the same time the earnings would have been taxed had the subsidiary been located in this country would remove the advantages of deferral and the accompanying incentive to invest in low-tax countries; moreover, separating the levy from the repatriation event removes the disincentive to have such an event occur. As repatriation will no longer trigger unpleasant financial ramifications, taxpayers will cease to avoid it.

This Article is far from the first to suggest that neutrality cannot be achieved unless and until payment of the federal catch-up tax is accelerated, thus eliminating the deferral advantage. ${ }^{130}$ Indeed, Congress has considered and rejected the idea on several occasions, fearing that accelerated taxation of their foreign subsidiaries would put American businesses at a disadvantage vis-a-vis their foreign competitors, leading to an overall net loss for the economy. ${ }^{131}$ I have little to add to

130 See, e.g., Federal Tax Reform for 1976, supra note 8, at 77-92; P. Musgrave, supra note 8, at 143-46, 161-62; Hartman, supra note 72, at 457-61; Isenbergh, Perspectives on the Deferral of U.S. Taxation of the Earnings of Foreign Corporations, 66 Taxes 1062, 1071 (1988); McClure, International Aspects of Dividend Relief, 7 J. Corp. Tax 137, 150 (1980); Stone, supra note 8 , at 563-64.

131 See P. McDaniel \& H. Ault, supra note 32, at 126-29 (recounting legislative proposals to eliminate deferral); Pugh, supra note 8, at 272-78 (recounting legislative history of deferral debate). 
the ongoing debate over whether the consequences of eliminating deferral would be catastrophic, insignificant, or favorable (except for the comments in Part III of this Article). My aim here is instead to point out that if we are serious about trying to attain defensive neutrality, deferral must be sacrificed. One cannot have a neutral system and deferral at the same time.

\section{Eliminating the Disincentive Effect of Foreign Second-Tier Taxes}

Eliminating deferral would eliminate only one of the two-and possibly the less important of the two-repatriation disincentives. The effects of foreign second-tier taxes imposed on U.S. parent corporations that receive dividends from their foreign subsidiaries ${ }^{132}$ would also have to be mitigated in order for defensive neutrality to be obtained. Several approaches appear promising; the question is which has the greatest likelihood of success.

One way the United States can ameliorate the effect of second-tier foreign taxes would be to absorb the cost of such taxes itself by reimbursing parent corporations for the amount of their second-tier foreign tax payments. Reimbursement could take the form of a tax credit, although in contrast to the present tax credit, this tax credit would have to be usable without limitation-and even refundable-to eliminate completely the economic burden of the foreign tax. ${ }^{133}$ Eliminating the economic burden of the foreign levy triggered by the repatriation of profits would, of course, remove the disincentive for such repatriations.

An argument can be made that such an unlimited ${ }^{134}$ credit for second-tier foreign taxes accords with general tax principles and, in particular, with the lodestar principle for taxing foreign-earned incomethe avoidance of double taxation. ${ }^{135}$ Ideally, second-tier foreign

132 See supra notes 102-07 and accompanying text.

133 Anything less would fail to absorb the full economic burden of the tax, leaving some economic disincentive to repatriation.

134 That is, not subject to the foreign tax credit limitation rules of $\S 904$.

135 See S. Rep. No. 313, 99th Cong., 2d Sess. 293 (1986); Revenue Revision, 1934: Hearings before the House Committee on Ways and Means, 73d Cong., 2d Sess. (1933), reprinted in Internal Revenue Acts of the United States 1909-1950: Legislative Histories, Laws, and Administrative Documents 77-78 (B. Reams ed. 1979); Surrey, supra note 119, at 74. Unfortunately, as discussed infra notes 136,140 , and 141, the solution is not quite as simple as eliminating the parent corporation's tax credit limitation; in addition, some American taxpayer's (either the corporate parent's or the individual shareholder's) income must be 
income tax should be credited against the U.S. income tax levied upon dividends received by individual taxpayers. ${ }^{136}$ After all, the secondtier tax is the foreign equivalent of our federal shareholder-level tax. ${ }^{137}$ Thus, to avoid duplicative taxation, second-tier foreign taxes

"grossed-up" by an appropriate amount, comparable to the "gross-up" rules of $\S 78$. See supra note 80 and accompanying text.

136 See J.D.R. Adams \& J. Whalley, supra note 23, at 116-17 (advocating pass-through of excess credit to shareholders as a solution to the "overspill" problem). For this alternative to work properly, the individual shareholder's dividend income must be "grossed-up" by the amount of the foreign withholding taxes "deemed paid" by the shareholder (and actually paid by the corporate parent), just as the corporate parent's income is "grossed-up" by $\S 78$ to reflect the amount of foreign taxes paid by the foreign subsidiary. Otherwise, the shareholder would be allowed tax benefits for payments made with money never included in the shareholder's income. The corporate parent, of course, must also continue to include the withholding taxes to the source country in its income. For example, under our "normal" tax rules, a domestic corporation $(D)$ that earns $\$ 100$ in pre-tax profits has to pay $\$ 34$ in U.S. corporate income tax, leaving $\$ 66$ for distribution to shareholders. An individual shareholder (I) receiving a $\$ 66$ dividend distribution has to include that dividend in her taxable income; assuming $I$ was in the 28 percent marginal tax bracket, this additional income would generate an additional federal income tax liability of $\$ 18.48$, leaving her with $\$ 47.52$ in after-tax income on account of the dividend distribution. By contrast, consider the effect of the current rules for the taxation of a foreign corporation $(F)$ that earns $\$ 100$ in pre-tax profits, on which it pays foreign income taxes of $\$ 30$, and which in the same year distributes all $\$ 70$ remaining to its U.S. parent $(P)$ in the form of a dividend. If the dividend distribution itself triggers a foreign withholding tax of $\$ 10, P$ would only receive $\$ 60$. Nonetheless, $P$ would be treated for U.S. tax purposes as receiving $\$ 100$ in dividend income, see I.R.C. $\S 78$, generating a U.S. corporate tax liability of $\$ 34$ (the same as $D$ 's), which would be completely offset by the available foreign tax credit of $\$ 40$. However, $P$, unlike $D$, would have only $\$ 60$ in after-tax profits to distribute to $I$; after paying a $28 \%$ income tax, $I$ would be left with only $\$ 43.20$. If the foreign withholding tax was "passed through" to $I, P$ would owe an additional $\$ 4$ of corporate income tax, leaving only $\$ 56$ for actual distribution to $I$ (though, with the "gross-up" amount, $I$ would be treated as receiving $\$ 66$ of dividends for U.S. tax purposes). However, I would only have to pay $\$ 8.48$ of federal income taxes out of the $\$ 56$ received from $P$ because $\$ 10$ of the $\$ 18.48$ total federal tax liability imposed as a result of the dividend distribution would be offset by the foreign tax credit attributable to the "passed-through" withholding tax. Thus, $I$ would be left with $\$ 47.52$ - exactly the amount she would have gleaned by investing in $D$.

137 See supra notes $93-100$ and accompanying text. This analogy becomes more tenuous, however, when the foreign country utilizes an integrated system, rather than a "classical" twotier system, for the taxation of corporate income. Under an integrated system, distributed corporate income is subject to only one level of tax. But this single level of tax can be exacted at staggered intervals, as is the two-tier tax levied under the classical system. Indeed, the European countries utilizing integrated tax systems do exactly that: Retained corporate profits are taxed at a corporate rate until distributed to shareholders; shareholder distributions trigger some combination of a corporate-level deduction, a lower tax rate on distributed amounts, and a shareholder credit. See Ault, International Issues in Corporate Tax Integration, 10 L. \& Pol'y Int'l Bus. 461, 463 n.12 (1978). In Germany, for example, the tentative corporate tax levied on retained earnings is set at $56 \%$. Distributed amounts are subject to corporate tax of $36 \%$; to the extent that the amounts distributed come from fully (56\%) taxed income, the 
paid should be credited against federal shareholder tax liability, just as foreign corporate taxes paid are credited against federal corporate tax obligations. ${ }^{138}$ However, the dividend distribution from the parent

corporation is granted a $20 \%$ income tax credit in the year of the distribution. See id. at 466 68. (However, the initial $56 \%$ tax is calculated against a tax base reduced by a variety of $\operatorname{tax}$ preferences, while the $36 \%$ tax is levied on a tax base stripped of all preferences, so that a distribution may in fact trigger an additional layer of "corporate" tax. Id. at 468.) Domestic shareholders include both the dividend and the amount of tax paid by the corporation with respect to that dividend in their income. The shareholders are then allowed a refundable tax credit for this "imputed" tax amount, which is offset against their individual income tax liability (levied at progressive rates). Id. at 466-67. Foreign shareholders, by contrast, are denied the "imputation credit" for the $36 \%$ corporate taxes paid, and they must pay an additional withholding tax at a rate established by treaty. Id. at 469-71. In short, for German shareholders, the corporate tax serves as a prepayment of their individual tax liability, whereas for foreigners, it becomes the first part of a two-part levy. Whether that two-part levy exceeds that imposed on similarly situated domestic (German) shareholders depends on the applicable withholding rate, the corporate tax rate, and the shareholder's individual tax rate.

Imputation systems have been attacked as discriminatory and unfair towards foreign investors (as well as their residence countries). See, e.g., id. at 465, 473 n.43, 486; Kingson, supra note 30, at 1197-98. For the purposes of this Article, however, imputation systems present two problems. First, the process of integration blurs the distinction between the "corporate" and "shareholder" levels of tax, so that it is difficult to tell whether the foreign withholding tax levy corresponds to the domestic second-tier tax or, instead, imposes a thirdlevel discriminatory tax. See Ault at 464 n.14; Kingson, supra note 30, at 1202, 1213. Second, and more importantly, the corporate tax payable at the time of distribution may be used by source countries to impose on such distributions the tax burden sought to be removed through the provision of an effective credit for the withholding tax. For further discussion of the problems for the international harmonization of tax systems created by integrated tax systems, see Ault at 461-94; Bryan, International and Corporate Double Taxation Problems in the Light of European Economic Community Proposals for the Harmonization of Company Taxation, 8 Ga. J. Int'l \& Comp. L. 833 (1978); Kingson, supra note 30, at 1194-262; McLure, supra note 130, at 137-49; Sato, International Aspects of Integration of the Corporate and Personal Income Taxes, 8 Ga. J. Int'l \& Comp. L. 779, 788-800 (1978).

138 If the foreign tax is not effectively credited against any federal income tax, the shareholder essentially pays two levels of tax on dividend income, in addition to the corporation's payment of a full corporate-level tax on the income from which the dividend is paid. Thus, transnational corporate dividend income bears three levels of tax, not just the two levels applicable to domestic corporate dividend income. One of those levels is duplicative. Though some may argue that this duplicative overtaxation results from the overreaching of source countries, who should be entitled to collect only the first-tier corporate tax, the argument that the United States should not absorb the cost of such overreaching by granting relief for foreign shareholder-level taxes suffers from two flaws. First, if levying a withholding tax on dividends constitutes overreaching, the United States is as guilty as any other country. See I.R.C. $\$ \S 871(a)(1), 881(a)(1)$ (Supp. V 1987) (levying withholding tax on foreign individuals and corporations receiving dividends from U.S. sources). A far more accurate characterization of the international "norm" is that source countries are entitled to a limited slice of the shareholder-level tax as well as the corporate-level tax. See, e.g., Model Double Taxation Convention on Income and Capital, art. 10, § II, If 1-2 (Organisation for Economic 
corporation to its shareholders may not take place for a number of years. If shareholders must postpone utilization of the credit until that time, the credit's value may substantially decrease, resulting in overtaxation. ${ }^{139}$ This overtaxation problem could be solved by increasing the initial credit by an interest charge for the deferral period, thus granting a larger credit in the year the shareholder distribution takes place. ${ }^{140}$ An economically equivalent alternative would be to allow the parent corporation to take an immediate tax credit for the full amount of the foreign tax payment in the year the payment is made. ${ }^{141}$ Granting either one of these expanded credits would place

Co-operation and Development 1977); Blum, supra note 93, at 595-96. Second, the question is not merely whether the United States has an obligation to reduce the burden of the foreign second-tier tax; it is also whether such relief would benefit the United States, and in particular, if it would spur sufficient repatriation of foreign earned profits to justify its costs, a question dealt with in Part III.

This second response also disposes of the somewhat better argument for denying relief, that foreign withholding taxes merely mimic the U.S. tax levied on the portion of intercorporate dividends not deductible under $\$ 243$. Though the actual burden of foreign withholding taxes may not exceed the burden imposed by the United States on transfers between multi-tiered corporations (though, in reality, it often will beeause, for example, a $15 \%$ withholding tax imposed on the entire dividend is a far greater levy than the taxation, at normal U.S. corporate rates, of the portion of an intercorporate dividend not deductible under $\$ 243$ ), the United States suffers little, if at all, if domestic corporations refrain from declaring dividends to avoid payment of the extra level of tax. By contrast, in the international situation, the United States is hurt when dividends are deferred.

139 It is now commonly understood that a dollar received today is worth more than a dollar received one year from now (even in the absence of inflation), because a dollar received now can be invested at a profit during the intervening year. For example, in a world with interest rates of $10 \%$ and marginal tax rates of $34 \%$, one dollar received today becomes (about) $\$ 1.07$ by year's end. Thus, if a taxpayer pays one dollar of foreign withholding taxes in year one, the United States' allowance one year later of a dollar of foreign tax credit would not completely eliminate the economic burden of the withholding tax; a credit of $\$ 1.07$ would be required to achieve this goal. And, of course, the longer the period between the payment of the withholding tax and the granting of the credit, the greater the disparity between the relief afforded by the credit and the burden of the the withholding tax would be.

140 See supra note 139. The "gross-up" amount, see supra note 136, would also have to be increased accordingly.

${ }^{141}$ Cf. M. Graetz, Federal Income Taxation: Principles and Policies 940 (2d ed. 1988) (demonstrating equivalence of deferring deduction until year of payment and allowing current deduction for present value of payment). To work properly, this alternative also requires that the individual U.S. dividend recipients "gross up" income to reflect the additional credit allowed. However, unlike the alternatives described supra notes 136 and 140, and infra note 143 , under this alternative, the gross-up would occur automatically. The allowance of an extra credit at the corporate parent level would increase the parent's after-tax profits available for distribution to shareholders by exactly the amount of the desired gross-up. The distribution of that increase in dividend form would then trigger the requisite shareholder-level tax on that 
the taxpayer on a tax par with other similarly situated taxpayers doing business in the United States. The disincentive to repatriate foreign earnings to this country would be removed, without costing the United States Treasury more money than the congressional rhetoric about the accommodation of foreign taxes suggests we ought to absorb. ${ }^{142}$

This argument makes one crucial, and not necessarily accurate, assumption-that the foreign second-tier tax does not exceed the federal tax collected from individual shareholders when they receive their dividend distributions. ${ }^{143}$ As a mechanical inatter, because the

gross-up amount. For example, suppose a foreign corporation $X$ has $\$ 70$ in profits left after paying foreign income taxes of $\$ 30$, distributes all $\$ 70$ to its U.S. parent $Y$, and the distribution itself triggers a foreign tax levy of $\$ 10$, so that $Y$ receives just $\$ 60$. Under current law, $Y$ would be treated as receiving a $\$ 100$ dividend with a $\$ 40$ tax credit attached, of which only $\$ 34$ would be allowable (assuming a 34\% tax rate) under the foreign tax credit limitation. Although $Y$ would not have to pay any additional federal tax, it would have only $\$ 60$ to distribute to its shareholder, $I$. If $Y$ were allowed to claim the $\$ 6$ of excess credit $(\$ 40-\$ 34)$, it would have $\$ 66$ to distribute to $I$ on account of the dividend distribution from $X$ (assuming it had $\$ 6$ of U.S. tax due on other income). After paying a $28 \%$ tax on that $\$ 66, I$ would have $\$ 47.52$ left-exactly the after-tax return that could be gleaned from $\$ 100$ in profits earned through a U.S. corporation taxable at a $34 \%$ rate, or through a foreign corporation taxable under a regime in which the foreign withholding tax was passed through to $I$ as described supra note 136. Granting the additional credit to the parent corporation rather than to the individual shareholder has two indisputable advantages. First, it provides tax relief to the entity most directly affected by the foreign dividend tax, which also happens to be the entity that directly controls the timing and existence of the subsidiary's dividend distributions. To the extent that the managers of the parent corporation are less concerned by the effect of the foreign dividend tax on the shareholders' ultimate tax burden than by its reduction of the assets under their own control (as they may be, for example, if the parent corporation rarely pays dividends), only tax relief granted to the parent corporation is likely to eliminate the managers' disinclination to have the subsidiary declare repatriating dividend distributions. Furthermore, making adjustments at the level of the parent corporation would ease the process of obscuring the difference between the first and second levels of foreign tax, a process that may well be desirable for the reasons discussed infra at note 143 .

142 See supra notes 23 and 135 and accompanying text (purpose of tax credit to relieve "double taxation").

143 The stated principle behind our tax credit policy is that the taxpayer's tax obligation shall be limited to the higher of the two tax levies, foreign and domestic. If the foreign secondtier tax is higher than the federal second-tier tax, the taxpayer should be excused from paying any federal second-tier tax on the foreign income but should not be held harmless for the excess foreign tax amount. Granting an unlimited credit for the foreign withholding tax would have the latter effect if the taxes being credited exceeded the U.S. shareholder's tax levy. On the other hand, strictly limiting the allowable credit for foreign shareholder-level taxes to the individual's federal tax liability with respect to the dividend may unduly interfere with another country's decision to couple relatively low corporate tax rates with relatively high individual income tax rates (as the United States did until relatively recently). It may be preferable 
amount of the federal shareholder tax levy depends on the economic situation of each shareholder in the year of the dividend distribution, ${ }^{144}$ there can be no guarantee that the tax rebated in the form of a credit will not exceed the federal levy on the corresponding dividend when it is received. ${ }^{145}$ More importantly, if the United States allows such an unlimited credit, foreign governments would have both the opportunity and the motivation to ensure that their second-tier taxes do exceed the comparable federal levy. Even if foreign second-tier taxes do not start out higher than the comparable U.S. tax, over time such growth could be expected.

The United States' adoption of an unlimited second-tier tax credit would thus place high-tax source countries in a no-lose situation similar to the one they would enjoy if the United States allowed an unlimited first-tier foreign tax credit. ${ }^{146}$ Raising their second-tier taxes to higher, even exorbitant, rates would engender one of two pleasant prospects for source countries. One possibility is that the United

initially to treat the foreign dividend tax as it is now treated for tax credit purposes, as a second installment of the foreign corporate income tax; only the excess credit, which the corporation is unable to apply against its U.S. corporate income tax, could then be treated as the exaction of a shareholder-level tax, credited in accordance with one of the procedures outlined supra at notes 136-41 and accompanying text, and limited accordingly. In short, perhaps no limitation should be imposed on the foreign tax credit until the total foreign tax levy exceeds both tiers of the U.S. income tax levy on corporate income.

An argument could be made that such treatment would be too generous, inasmuch as the taxes levied on dividends paid to foreigners tend to be constructed for, and imposed solely upon, foreign investors, see supra notes $95-100$ and accompanying text, and as such could very easily be constructed to impose a discriminatory burden on U.S. investors. Our tax system should not make it easier for source countries to levy such discriminatory taxes, but allowing a source country to mask its discriminatory shareholder tax as an add-on corporate tax would do exactly that. On the other hand, not all high shareholder taxes are discriminatory in purpose or effect. Our interest in international comity, as well as the existence of alternative methods for attacking discriminatory regimes when they exist, argues against enacting a taxing regime that assumes high shareholder taxes are discriminatory rather than part of a tax system designed in good faith.

144 The tax rate applied to the dividend income will be a function of the shareholder's income for the year. See I.R.C. $\S 1$ (Supp. V 1987) (progressive rate schedule).

I45 The most that can be determined is whether the foreign second-tier tax would exceed the corresponding federal individual income tax that the shareholder would incur if the dividend were distributed to the shareholder in the same year that the distribution to the U.S. parent corporation takes place. Both the identity and financial characteristics of the shareholders may change (in unpredictable ways) between the year of the distribution to the domestic corporation and the year in which that corporation distributes the profits to its individual shareholders.

I46 See supra notes 41-90 and accompanying text. 
States would continue to reimburse U.S. investors for the full amount of the excess levy, so that future investors would not be deterred from making new investments in high-tax source countries, while the tax revenues, now subsidized by the U.S. government, could be used to spur further economic growth in the source countries. Alternatively, Congress could decide to limit reimbursements, resulting in the restoration of a repatriation disincentive for U.S. investments already in the source countries (the amount of which would likely be inflated due to the temporary U.S. tax concession), accompanied by only a slight increase in the source countries' tax revenues. ${ }^{147}$ It is hard to know which of the two alternatives source countries would prefer; the only thing that is certain is that they would regard both as preferable to the status quo.

For the United States, of course, neither of these options is preferable to the status quo. The first option provides source countries with a mechanism for obtaining foreign aid outside of the appropriations process and largely beyond congressional review; indeed, it was largely the specter of such an unlimited drain on the federal treasury that led to the enactment of the original foreign tax credit limitation in 1921. ${ }^{148}$ The second alternative places the United States back where it started vis-a-vis the repatriation of American capital, simultaneously costing some additional tax revenues. ${ }^{149}$ In short, what appears at first to be a promising solution, upon further reflection turns out to be a recipe for disaster because of the impact that other

147 Any increase in the U.S. tax credit allowance would allow source countries to raise taxes by the amount of the increase without suffering a reduction in investment, for by definition, the United States Treasury, rather than thc investors, would pay for the tax increase. Indeed, allowing an unlimited credit for second-tier taxes would provide an even better opportunity for foreign countries to raid the United States Treasury than would an unlimited credit for firsttier taxes, for, as a general rule, the withholding taxes imposed on foreigners do not apply to domestic investors; hence, the source country would not have to worry that the increase in taxes on foreign investors would provide a disincentive to domestic investors. See supra note 45. Finally, taxes on investors from countries utilizing exemption systems could be reduced by treaty without generating a plausible claim of discrimination against, and hence a risk of denial of tax credit for, U.S. investors.

148 See supra notes $46-47$ and accompanying text.

149 Each dollar of additional credit allowed as an offset against a taxpayer's U.S. tax liability costs the Treasury one dollar of revenue. Thus, to the extent that providing tax credit for second-tier foreign taxes allows taxpayers to claim credit that would, under the present rules, be treated as excess credit, the Treasury loses money. 
countries with contrary interests can have on its operation. A unilateral solution simply is not workable.

The unsuitability of unilateral solutions to international tax problems long ago led to attempts at bilateral, and nore recently, multilateral, ${ }^{150}$ cooperation in the form of tax treaties. ${ }^{151}$ Such treaties are used to define the terms and conditions under which each signatory country may tax the income derived by its residents in the other country, as well as to what extent it may tax the income derived by the other country's residents within its borders. ${ }^{152}$ Fron a niechanical standpoint, it would be both possible and plausible to solve the two-tier tax problem by entering into tax treaties that eliminate source countries' right to levy a second-tier tax. Indeed, one of the nuajor purposes of tax treaties today is to limit source countries' power to tax dividends and other passive inconie derived within their borders by residents of other contracting states. ${ }^{153}$

Because such agreements reduce tax revenues, however, a source country does not agree to eliminate withholding taxes on dividend incone without receiving equally valuable concessions from the nego-

150 The United States will enter its first multilateral tax treaty if it signs the Multilateral Convention on Mutual Administrative Assistance in Tax Matters, a treaty jointly developed by the Council of Europe and the Organisation for Economic Co-operation and Development. See Daily Tax Rep. (BNA) No. 25, at H-1 (Feb. 8, 1988). Although the Treasury Department is on record as "supporting" the ratification of the agreement, see U.S. Supports Multilateral Convention on Mutual Assistance in Tax Matters, 3 Tax Treaties (CCH) ๆ 9822 (1987) (letter of J. Roger Mentz, Assistant Secretary of the Treasury (Tax Policy)), the Senate has yet to ratify it.

151 More than one thousand bilateral tax treaties have been signed worldwide, most in the post-World War II era. See Burke, Preface to New York State Bar Association Tax Section, Committee on United States Activities of Foreign Taxpayers, Report on Proposed United States Model Income Tax Treaty, 23 Harv. Int'l L.J. 219, 220 (1983). The United States is a party to about 40 such treaties at the current time. See id.; $R$. Kaplan, supra note 5 , at 332.

152 See R. Hellawell \& R. Pugh, supra note 19, at 201 (tax treaties "carv[e] out the respective taxing powers of the partners"); $R$. Kaplan, supra note 5, at 332 ("Tax treaties are agreements between two nations that seek to harmonize their respective tax systems, prevent double taxation of their citizens' income, and provide special incentives for bilateral investment.").

153 See, e.g., R. Hellawell \& R. Pugh, supra note 19, at 201 ("The major substantive thrust" of tax treaties "is to limit taxation by the source country."); P. McDaniel \& H. Ault, supra note 32, at 173 ("U.S. treaties generally ... provid[e] for a reciprocal reduction of rates (often to zero) for investment-type income."). Indeed, the fact that tax treaties are oriented in this direction has led many underdeveloped countries, which are typically only source countries, to negotiate for treaties that allow greater source-country taxation. See U.N. Centre on Transnat'l Corps., supra note 29 , at $27-28$. 
tiating residence country. ${ }^{154}$ If a source country doubles as, a residence country-that is, if its residents have business interests in the United States approximately equal in scale to those of U.S. investors there -an even exchange can be, and often is, worked out fairly easily. ${ }^{155}$ The United States forgoes its claim to a second-tier tax on the other country's investors in exchange for the other country's relief of its second-tier tax liability on U.S. investors. Each country's tax revenues remain approximately the same; they are just collected from a different set of taxpayers.

Unfortunately, our record of carrying out such bargains in tax treaties has been mixed at best. The causes of these difficulties are sufficiently complex to require independent treatment; ${ }^{156}$ all I attempt here is a brief sketch of some of the problems. One source of difficulty has been the failure of our negotiators to comprehend and protect the United States' interests, ${ }^{157}$ resulting in the adoption of treaty provisions that allow other countries to obtain disproportionate profits at the expense of the U.S. government and its investors. ${ }^{158}$ Congress's frustration with the tax treaty process has recently been expressed in a form that will add considerably to the difficulty of negotiating further treaties - the almost reckless passage of legislation overriding existing treaties. ${ }^{159}$

154 See U.N. Centre on Transnat'I Corps., supra note 29, at 28; Kingson, supra note 30, at 1224.

155 See U.N. Centre on Transnat'l Corps., supra note 29, at 27; Kingson, supra note 30, at I169; see also R. Rhoades \& M. Langer, Income Taxation of Foreign Related Transactions $\S 12.02[3]$, at $12-13$ to $12-17$ (1988) (discussing various U.S. tax treaties).

156 Discussions of some of the problems encountered in negotiating and administering treaties can be found in Kingson, supra note 30 , at $1168-79$, and Note, supra note 119, at 38897.

157 See Kingson, supra note 30, at 1213-14 (arguing that a misconceived negotiating position "caused reactions harmful to American interests").

158 See id. at 1212-13, 1258-60.

159 Until the passage of the 1986 Act, treaty rules prevailed over conflicting domestic tax laws unless Congress clearly indicated to the contrary, a prerogative that Congress infrequently exercised. See Committee on U.S. Activities of Foreign Taxpayers and Foreign Activities of U.S. Taxpayers of the New York State Bar Association Section of Taxation, Legislative Overrides of Tax Treaties, 37 Tax Notes 931, 932 (1987) [hereinafter NYBA Tax Section]; see also I.R.C. $\$ \S 894(a), 7852$ (d) (1982) (providing for priority of treaty obligations). But see Foreign Investment in Real Property Tax Act of 1980, Pub. L. No. 96-499, § 1125(c), 94 Stat. 2682, 2690 (expressly overriding $\$ \$ 894($ a) and 7852 (d), but providing a four-year grace period before override begins); Revenue Act of 1962, Pub. L. No. 87-834, § 31, 76 Stat. 960,1069 (expressly overriding $\$ 7852$ (d) for "any amendment [to the Code] made by this Act"). At least when the 1962 Act was passed, however, no such conflicts were envisioned. 
Furthermore, many countries do not have (as in the case of relatively undeveloped countries), or are unwilling to act on the assumption that they will continue to have, offsetting residence interests. ${ }^{160}$ Designing an acceptable and appropriate bargain in such cases may well be impossible. Often, the bargains acceptable to the source countries merely substitute one incentive for the exportation of American capital for another. ${ }^{161}$ In order to negotiate from a position of

See H.R. Conf. No. 2508, 87th Cong., 2d Sess. 48 (1962). In the 1986 Act, Congress provided that section $904(\mathrm{~g})$ of the Code, already in force, would override any contrary treaty provisions, past, present, or future, unless the treaty specifically provides otherwise. Pub. L. No. 99-514, §1810(a)(4), 1986 U.S. Code Cong. \& Admin. News (100 Stat.) 2085, 2822-23. See NYBA Tax Section, supra, at 931. In the course of the ensuing debate over those provisions, the House Ways and Means Committee included in its version of a proposed technical corrections bill a provision that would reverse the general presumption in favor of treaty validity for one favoring subsequently enacted conflicting legislation. See Staff of Joint Comm. on Tax'n, 100th Cong., 1st Sess., Description of the Technical Corrections Act of 1987, at 233-35 (Joint Comm. Print 1987) (describing section 112(y)(2)(c) of the proposed act). The Senate subsequently included a somewhat milder version of the override provision in its version of the technical corrections bill, see Matthews, Treasury Encouraged by Finance Treaty Override Substitute, 40 Tax Notes 662 (1988) (questioning whether the Senate Finance version in fact differs significantly from the House Ways and Means version). The Senate version of the override provision was finally enacted as part of the Technical and Miscellaneous Revenue Act of 1988, Pub. L. No. 100-647, § 1012(aa)(1)(A), 1988 U.S. Code Cong. \& Admin. News (102 Stat.) 3342, 3531 (to be codified at I.R.C. $\S 7852$ (d)). See H.R. Conf. Rep. No. 1104, 100th Cong., 2d Sess. 15 (1988). Section 7852(d)(1) now reads that, in determining priority between a treaty and the Code, "neither the treaty nor the law shall have preferential status by reason of its being a treaty or law." I.R.C. $\$ 7852$ (d)(1) (West Supp. 1989).

160 In the case of underdeveloped countries, it is clear that the investment stream is mostly one-way. See U.N. Centre on Transnat'1 Corps., supra note 29, at 27. However, a number of countries that would ordinarily be classified as developed countries take the same position in negotiations with the United States. See Kingson, supra note 30, at 1169-70 (France, Japan Canada, Italy, Australia, New Zealand). And, of course, just because a country is primarily or equally a residence country with respect to some countries does not guarantee that it maintains that position vis-a-vis the United States. As treaties are usually bilateral agreements, the terms a country grants one treaty partner may not be offered to another with a different direction of investment flows.

161 For example, many underdeveloped countries will trade some reduced source taxation for "tax-sparing" arrangements under which residence countries agree to credit their investors for foreign taxes that have been waived rather than collected by the source country. See $R$. Hellawell \& R. Pugh, supra note 19, at 239-40; U.N. Centre on Transnat'l Corps., supra note 29, at 28; Miller, Third World Views of the Ends and Means of United States Tax Policy, in United States Taxation and Developing Countries 83, 93 (R. Hellawell ed. 1980). Such waivers are granted by source countries in order to attract foreign investors; in the absence of a tax-sparing arrangement, the waiver often merely transfers tax revenues from the source country treasury to the residence country treasury, thus undercutting the source country's goal of attracting additional investment. See R. Hellawell \& R. Pugh, supra note 19, at 240; Miller, 
strength (and avoid having to make such unpalatable bargains), Congress inight try to gain additional leverage by viciously overtaxing investors from those countries on income derived in the United States; however, such tactics are unlikely to work. ${ }^{162}$ Overtaxing U.S. residents investing abroad, another method of gaining additional leverage, would likely be politically unacceptable. ${ }^{163}$ In short, unless the underlying facts are just right, tax treaties usually perpetuate preexisting problems, albeit sometimes in slightly altered form. The underlying realities inay be quite difficult to change.

The impossibility, under present conditions, of completely elinninating the foreign second-tier tax barrier does not mean that steps cannot be taken toward its reduction. An option capable of producing linited relief and, moreover, one that can be put into place on a unilateral basis, does exist. That option would take advantage of the fact that the United States is party to a number of tax treaties that limit the source country's right to levy a shareholder-level dividend tax well below the resident country's personal income tax rates. Wherever such limits exist, it is possible to allow taxpayers ${ }^{164}$ to clain credit for their second-tier foreign tax, in addition to the credit allowable with respect to first-tier taxes incurred, without providing source countries with a mechanism for obtaining unlinited foreign aid. Allowing an unlimited tax credit under these circumstances would

supra, at 98. Of course, merely stating the source countries' reasons for instituting such a policy of waivers illustrates the problem with effectuating them through tax-sparing agreements: to do so allows the waiving country to influence investment patterns by utilizing tax incentives, the elimination of which are the sine qua non of a capital export neutral tax regime. See Surrey, supra note 8, at 856 ("The arguments in favor of tying United States tax rates to foreign tax concessions are no more valid when considered in the context of a treaty than in the context of congressional legislation.").

162 In the first place, the offending jurisdiction may not have enough investors in this country to make such retaliation possible. Furthermore, as the immediate consequence of such Draconian measures is to make the United States an unattractive investment spot, such retaliation might actually serve the foreign jurisdiction's interests better than those of the United States. The other jurisdiction may be more interested in discouraging its investors from investing here, hoping that they will invest at home instead, than it is concerned about the profitability of the investors' foreign investments. The jurisdiction's attitude toward such retaliation, in short, probably depends on the ease with which the investments could be, and likelihood that they would be, repatriated in the face of adverse American actions.

163 See Kingson, supra note 30 , at 1251 (detailing history of avoiding retaliatory measures).

164 The taxpayer might be a parent corporation or an individual shareholder, depending on which approach Congress chose to effectuate the unlimited second-tier tax credit. See supra notes 136,140 , and 143 . 
bring U.S. investors in treaty countries much closer to a position of neutrality in deciding whether to declare dividends back to the U.S. parent. In short, where the level of second-tier taxation is frozen by treaty, the United States can match reality and rhetoric without running an uncontrollable financial risk. Unfortunately, even this limited relief from the pressures against capital repatriation comes at a financial cost, in the form of reduced U.S. revenues, because some credits that are now unusable would have to be allowed. ${ }^{165}$

Would this limited improvement in the defensive neutrality of our tax system be a good idea? The first two Parts of this Article illustrate how far our tax rules deviate from the neutrality goal we profess to believe in and the steps we must take to bring the system closer to that goal. Those steps, as the above discussion explains, may be costly for taxpayers and government alike. The question for the balance of this Article is whether achievement of the goal is worth the pain its achievement will cause.

\section{The EfFects OF NeUtrality}

Efforts to obtain defensive neutrality have never been justified in nationalistic terms. Rather, the stated justification for its attainment has been worldwide progress. If the pursuit of tax advantages is removed from the list of factors influencing investment decisions, it is argued, capital will flow to its highest valued use, wherever that may be, leading to the highest possible level of human productivity and

165 To some extent, to follow the suggestions outlined in this Article so far would have Congress take back with its left hand what it is giving with the right: For every extra dollar of credit granted with respect to the foreign second-tier tax, one dollar of credit might be taken away by tightening the foreign tax credit restrictions. What would change, even if the total dollars collected by the government did not, would be the timing of the various tax collections. More dollars would be collected earlier, in the year the foreign subsidiary earns money, and fewer dollars would be collected in the year of the dividend distribution to the U.S. parent. Since time is, after all, money, the acceleration of the tax revenues may in fact benefit the United States Treasury directly. Even if the opposite is true (because, for example, source country taxes are at least as high as U.S. income taxes on corporations, see Hartman, supra note 72 , at 459 (predicting source countries will raise tax levels to the extent of foreign tax credit, usurping putative U.S. revenue from elimination of deferral); Kingson, supra note 30 , at 1270 (predicting elimination of deferral will not raise much revenue), however, it is at least arguably the case that altering the timing of the tax collections would benefit the federal fisc indirectly, by encouraging more investors to repatriate their foreign profits and invest them in the United States. The prospects for such advantageous results are discussed more fully in Part III of this Article. 
wealth (and presumably, happiness). ${ }^{166}$ Of course, this justification makes no explicit representation about how this wealth will be distributed among particular countries or individuals, or how such countries' or individuals' absolute and relative wealth under such a system will differ from the status quo. ${ }^{167}$ It may therefore be unfair to ask whether pushing closer to achievement of that goal is now in our national interest. Yet, because the costs of trying to edge closer to the neutrality goal are so high, it seems ridiculous to urge their assumption without first examining whether those costs will bear a reasonable return. The answer to that inquiry is more problematical than one might think.

This Article began with the observation that, under certain circumstances, our failure to attain defensive neutrality hurts the United States' interests. Specifically, our present tax rules encourage capital exportation over capital retention both when an investment in a hightax jurisdiction is specially desired or required and when profits have been earned abroad through a foreign subsidiary. In the first case, offsetting investments in low-tax countries become especially lucrative, and in the second, reinvestment abroad postpones the imposition of foreign second-tier taxes and sometimes domestic catch-up taxes. A neutral tax system would eliminate the incentive for investment in foreign locales, rather than the United States, in both of these circumstances.

Changes in the direction of defensive neutrality, however, would affect investors in other circumstances as well. In particular, eliminating the financial burden of second-tier foreign taxes by providing credit for their full amount would tend to encourage additional investment abroad. Although one result of the current rules is that taxpayers earning money abroad continue to invest such funds abroad rather than to repatriate them, the presence of this additional tax burden is likely to deter some investors from investing abroad in the first

166 See P. Musgrave, supra note 8, at 104-07; Gumpel, supra note 8, at 397; Hufbauer, A Guide to Law and Policy, in U.S. Taxation of American Business Abroad 1, 2 (American Enterprise Institute-Hoover Policy Study No. 16, 1975).

167 Indeed, most economists seem to believe that the United States would maximize its national welfare by discriminating against foreign investment, that is, by taxing it more heavily than domestic investment. In particular, various economists suggest that our national welfare would be best served by replacing the foreign tax credit with a deduction for foreign income taxes. See R. Caves, supra note 28, at 229-31; P. Musgrave, supra note 8, at 134; see also Gumpel, supra note 8, at $398 \mathrm{n} .51$ (collecting additional sources). 
instance. ${ }^{168}$ After all, not all taxpayers have the financial flexibility to eliminate that burden with offsetting investments in low-tax countries. Thus, the second-tier tax can be viewed as an additional expense of operating abroad, particularly if the taxpayer expects to require access to the foreign earnings in the near future. ${ }^{169}$ For a taxpayer on the margin of investing abroad or at home, that additional expense may make the deciding difference-and its removal may cause a different investment decision to be made.

Whether eliminating the effect of the second-tier foreign tax will lead to more or less investment abroad overall is therefore uncertain. While some foreign-earned profits that would have remained abroad will likely be repatriated, additional U.S. capital is likely to be moved abroad once the tax disadvantages of doing so are reduced. In short, while profits on old investments may be more likely to return to the United States, funding for new investments will be more likely to leave.

Moreover, to the extent that the effect of second-tier taxation is ameliorated through mutual treaty concessions, rather than unilateral action, the United States is likely to lose investments made in this country by foreigners as well. The second-tier tax effect that works against our interests as a residence country operates to our benefit in our role as a source country; foreign investors in the United States are dissuaded from repatriating locally generated profits for the same reasons, and to the same extent, ${ }^{170}$ that U.S. investors are deterred from

168 An obvious question is why more investors were not discouraged initially. To some extent, the answer may lie in timing: Tax rates in Europe and elsewhere may have been lower than the corresponding U.S. rates at the time initial investment decisions were made. Divesting when this situation changed may have been both organizationally and financially undesirable for many taxpayers. See Wang, Code of Conduct and Taxation of Transnational Corporations, $8 \mathrm{Ga}$. J. Int'1 \& Comp. L. 809, 811 (1978) (describing how countries raised taxes on companies "already heavily invested in the host country and, therefore, virtual hostages"). Further, nontax business imperatives and cost savings may dictate initial and even continued investment abroad, almost irrespective of the tax consequences.

169 Such taxpayers are not able to reap the benefits of deferral of the catch-up tax. See supra notes 83-85 and accompanying text.

170 This assertion must be qualified by one caveat. In the past, the United States has been rather remarkably lax about collecting a second-tier dividend tax from foreign investors. Indeed, the Code allowed investors to escape the tax entirely to the extent U.S. income was earned by a corporate entity earning largely foreign-source income. See I.R.C. $\$ 861$ (a)(2)(A) - (B) (1982). The enactment of a branch profits tax as part of the 1986 Tax Act largely remedied this problem. Cancellation and renegotiation of many of our tax treaties to include "anti-treaty shopping" provisions has largely eliminated another avoidance route, investors' 
repatriating their foreign-earned profits. The elimination by treaty of the federal second-tier tax burden would make foreign investors more likely to use their American-generated profits elsewhere, though some offsetting increase in initial foreign investments could also be expected. As the Uinted States is increasingly a source country, ${ }^{171}$ these effects on foreign investment cannot be ignored.

In short, although the identity of owners of U.S. investments may change somewhat as a result of the introduction of greater neutrality in the tax system, it is far from certam that overall investment in the United States will increase. It is thus far from clear that the benefits of obtaining greater neutrality justify the costs involved for taxpayers and the government.

The most significant effect of changing the rules, however, may not be their direct impact on American taxpayers, but the indirect effects on American and foreign taxpayers resulting from corresponding changes inade by other nations. Although no nation copies our tax legislation word for word, other countries, especially other developed countries, often use U.S. tax developments as a basis for reforming their own tax systems. ${ }^{172}$ If Congress decided to take defensive neutrality seriously and adopt the changes sketched in Part II of this Article, other countries inight follow suit, either in retaliation or

use of foreign entities incorporated in unrelated foreign (and usually tax haven) jurisdictions with tax treaties exempting their "residents" from the secondary withholding tax for purposes of holding their U.S. investments. One avoidance route, however, appears to remain largely uncontrolled. Recent studies have revealed that foreign investors' direct investments in the United States generate comparatively less taxable income than those of their domestic competitors. See Wheeler, supra note 125 , at 89 . Although these returns may reflect economic realities, various commentators have speculated that foreign investors are using artificially inflated transfer prices to avoid both their first- and second-tier tax obligations in the United States. See id. at 95 . Profits that should be taxed twice in the United States, it is alleged, are escaping the country disguised as the payment of expenses without being subject to any tax. To the extent these allegations are true, of course, foreign investors are not currently dissuaded from repatriating their U.S. earnings, and eliminating the second-tier tax "burden" would not have any effect on their behavior.

171 See supra note 16.

172 For example, the subpart $F$ provisions enacted by Congress in 1962 have been adopted in modified form by a number of other countries. See R. Gordon, supra note 6, at 24-26 (describing similar German, Canadian, French, and Japanese regimes); Tillinghast, The Contributions of Stanley S. Surrey to the International Aspects of Taxation, 38 Nat'l Tax J. 267, 269 (1985) (same). See also Arnold, supra note 26, at 7-10 (describing derivation of U.S., Canadian, Japanese, French, and U.K. systems). 
because they believe the legislation to be a good idea. ${ }^{173}$ Thus, in evaluating rule changes, the effect of copycat legislation must be considered. Unfortunately, it appears that such legislation might leave the United States in a worse, rather than better, position.

Consider for a moment what would happen if the United States and other countries eliminated deferral entirely. Compared to the rest of the developed world, the United States exacts a relatively low income tax burden. ${ }^{174}$ As a result, investors from many other countries gain a tax advantage from investing in this country rather than their own. ${ }^{175}$ This advantage would disappear, of course, if other countries that currently allow deferral, or indeed operate under an exemption system, decided to mimic the United States and eliminate deferral through the levy of an immediate catch-up tax. If such an event occurred, fewer investors from other countries would invest in the United States.

Similarly, if other countries followed our lead in unilaterally compensating for the effect of second-tier foreign taxes on their investors, foreign investors presently in this country might well decide to repatriate more of their American-earned profits. Although the lessened tax burden on foreigners' investments in this country might encourage some new foreign investors to come here, it is certainly possible that the result would be a net outflow, rather than inflow, of foreign capital. ${ }^{176}$

The possibly deleterious, and certainly uncertain, impact of changes in the tax rules cannot be ignored. After all, for the first time in recent memory, foreigners now own more assets in the United

173 Indeed, at least one economist believes that some retaliatory action would be "optimal" from the point of view of the affected countries. See Hartman, supra note 72, at 459 .

174 See Baker, The Momentum of Tax Reform in Tax Policy in the Twenty-First Century 1, 5 (H. Stein ed. 1988); Pechman, Introduction, in World Tax Reform: A Progress Report 1, 4-5 (Brookings Dialogues on Public Policy, J. Pechman ed. 1988).

175 If the investor's home country utilizes a credit system similar to ours, they can glean a deferral advantage from investing here, just as U.S. investors glean advantages from investing in low-tax jurisdictions. If their home country utilizes an exemption system, the tax advantages of investing in the United States are even greater. Of course, to the extent that jurisdictions with lower taxes exist, the foreign investors could glean still greater tax advantages by investing there instead; however, not all investment opportunities can be replicated in those countries.

176 Cf. supra notes 168-71 and accompanying text (discussing uncertain impact of reductions of dividend tax on amount of U.S. investment by U.S. investors with overseas operations). 
States than Americans own abroad. ${ }^{177}$ Of course, gross investment amounts do not tell the whole story-the pertinent question is how many of those investments are marginal enough that a small shift in tax burdens would affect their profitability significantly enough to cause an expatriation or repatriation of capital. Nonetheless, the gross investment figures do impart a sense of relative scale, and on a relative level, the trade-off looks precarious-particularly given the effect that a push toward neutrality would have on some domestic investors.

In sum, calls for further reform of our international tax rules in the direction of further neutrality are fundamentally misdirected. Not only is it true that further efforts in this direction can be made only at great expense and with problematical effectiveness; in addition, the end results may very well be the opposite of those the reformers expect. And this sorry conclusion does not even take into account one of the traditional arguments raised in defense of the status quothat deferral is necessary to keep our investors competitive in overseas markets. ${ }^{178}$ If the traditional reasons for deferral are correct, the case for further reform of our international tax rules is even weaker.

Of course, this analysis is premised on the assumption that the total amount of worldwide investment will not change as a result of changes in our tax rules. Perhaps the elimination of inefficiencies in capital allocation encouraged by nationalistic tax rules would cause the economic pie to grow sufficiently so that this country would be better off on an absolute scale, even if it is worse off on a relative scale, under a neutral regime. But before such economic growth could possibly occur, other countries would also have to adopt neutral tax systems. Until that happens, the United States is caught on the horns of a classic "prisoner's dilemma." Unilateral action to "improve" our international tax rules is more likely to lead to exploitative behavior

177 See supra note 16.

178 If American investors are denied the favorable tax treatment allowed local investors, the argument goes, over time the local investors (or investors from other countries that utilize either deferral or exemption systems) will drive the Americans out of the market entirely because their tax advantage will translate into a price advantage or an increased ability to expand capacity and saturate the market. Thus, the end results will be fewer U.S. jobs and tax revenues, rather than more. See, e.g., Lynn \& Wiacek, Keep "Deferral": U.S. Shareholders Should Not Be Taxed on Foreign Corporation Income Before They Receive It, reprinted in W. Gifford \& E. Owens, 2 International Aspects of U.S. Income Taxation: Cases and Materials $132,137-40$ (1982). 
by other affected countries than to their cooperation. The stakes are too high and the gains from cooperation in an unenforceable bargain are too uncertain to induce systemic cooperation. Reducing marginal tax rates, the international as well as the domestic trend over the last five years, may well do more to reduce tax-induced distortions im investment decisions than can be achieved by elaborate structural reforms. 
